\title{
Agricultural innovation and resilience in a long-lived early farming community: the 1,500-year sequence at Neolithic to early Chalcolithic Çatalhöyük, centralAnatolia
}

\author{
Amy Bogaard, ${ }^{1}$ Dragana Filipović, ${ }^{2}$ Andrew Fairbairn, ${ }^{3}$ Laura Green, ${ }^{1}$ Elizabeth Stroud, 1 \\ Dorian Fuller ${ }^{4}$ and Michael Charles 1 \\ ${ }^{1}$ University of Oxford, UK, ${ }^{2}$ Serbian Academy of Sciences and Arts, Serbia, ${ }^{3}$ The \\ University of Queensland, Australia, ${ }^{4}$ University College London, UK \\ amy.bogaard@arch.ox.ac.uk
}

\begin{abstract}
Intensive archaeobotanical investigations at Çatalhöyük have created a unique opportunity to explore change and conti- nuity in plant use through the ca 1,500-year Neolithic to early Chalcolithic sequence of an early established farming community. The combination of crops and herd animals in the earliest (Aceramic) part of the sequence reflects a distinct and diverse central Anatolian 'package' at the end of the eighth millennium cal. BC. Here we report evidence for near continual adjustment of cropping regimes through time at Çatalhöyük, featuring recruitment of minor crops or crop contaminants to become major staples. We use panarchy theory to frame an understanding of Çatalhöyük's long-term sustainability, arguing that its resilience was a function of three key factors: its diverse initial crop spectrum, which acted as an archive for later innovations; its modular social structure, enabling small-scale experimentation and innova- tion in cropping at the household level; and its agglomerated social morphology, allowing successful developments to be scaled up across the wider community. This case study in long-term sustainability through flexible, changeable cropping strategies is significant not only for understanding so-called boom and bust cycles elsewhere but also for informing wider agro-ecological understanding of sustainable development in central Anatolia and beyond.
\end{abstract}

\section{Introduction}

Intensive archaeobotanical recovery and analysis since 1995 at Çatalhöyük have yielded an archive of over 10,000 samples. Rapid scanning of every sample in the field, combined with prioritisation of those from in situ burning events (for example hearths, ovens, rakeouts, adjacent 'dirty' floors and burned buildings), has resulted in full analysis of over 600 samples to date (Fairbairn et al. 2005; Bogaard et al. 2013; Filipović 2014; Charles, Bogaard in preparation; Stroud et al. in preparation). Çatal- höyük's archaeobotanical assemblage is one of the largest ever recovered from a Neolithic site in western Asia and offers unparalleled insight into plant-related activities across the settlement and through time. Spanning a ca 1,500-year sequence of Neolithic to early Chalcolithic occupation (East Mound: ca 7100-5950 BC; West Mound: 6000-5500 BC: Bayliss et al. 2015; Marciniak et al. 2015; Orton et al. in preparation), the archaeobotanical assemblage offers the opportunity to build, for the first time, a highresolution picture of how early established farming was sustained locally over the longterm. 
As with all sedentary, food-producing societies, Çatal- höyük was subject to a number of risk factors that could undermine its ability to sustain the settlement's population. A particular risk factor was variability in precipitation in this semi-arid zone - the southern Konya plain is one of the driest regions of Turkey - affecting not only water availability for crops but also local hydrology across the runoffdependent alluvial fan of the Çarşamba river, which flows past the site (Roberts, Rosen 2009; Ayala et al. forthcoming). A further risk factor would have been the growing population of the site itself, which peaked at least in the low thousands in the mid seventh millennium BC (Cessford 2005).

Here we report evidence for near continual adjustment of cropping regimes through time, featuring recruitment of minor crops or crop contaminants to become major staples. We argue that certain shifts in cropping practice by Çatalhöyük farmers reflect the ecological challenges of farming in a mosaic of local environments, and in partic- ular of coping with aridity, while others articulate with changes in material culture and other aspects of subsis- tence practice and cuisine. We also observe change as well as continuity in the use of fruit and nut resources. The available data suggest that certain innovations in plant use and husbandry began in particular households or neigh- bourhoods and were subsequently adopted by the wider community: a gradual pattern of change noted also in aspects of material culture (for example mudbrick materials: Love 2013; pottery fabrics: Yalman et al. 2013; chipped stone raw materials and technology: Carter, Milić 2013). We use panarchy theory (Gunderson, Holling 2001; Holling 2001) to frame these patterns, arguing that exper- imentation and innovation at small social scales insulated the wider community from risks of failure, prior to scaling up of successful innovations in cropping strategy. Several innovations cluster in the mid Neolithic sequence and were widely adopted just after the community had attained its maximum size and showed signs of reorganisation (Hodder 2014c). It is plausible that such developments played a key role in maintaining resilient, flexible responses (Holling 1973) to the challenges of farming, enabling remarkably long-term sustainability through change. Given recent interest in apparent 'boom-andbust' cycles in the western European Neolithic (for example Downey et al. 2016), the Çatalhöyük sequence offers the opportunity to consider how a community managed the long-term challenges and risks of established farming.

\section{The Anatolian background}

Table 1 summarises the archaeobotanical data currently available for central and eastern Anatolia, from the late Pleistocene to the end of the eighth millennium cal. $\mathrm{BC}$, while figure 1 shows the locations of relevant sites. The emerging picture will be corrected and refined by ongoing work at Aşıklı (Özbaşaran 2012) and Boncuklu (Baird et al. 2012), and restudy of the Can Hasan III assemblage (Fairbairn, Hillman forthcoming), but some general trends are evident. As noted by Fairbairn et al. (2014), first, pre- agricultural nut use in cave/rockshelter sites is evidenced in southwestern (Ökuzini) and central Anatolia (Pinarbaşı). Second, more diversified plant use, sometimes including cultivation, emerges alongside hunting in open-air 'seden- tarising' communities of southeast/eastern Anatolia (Hallan Çemi, Demirköy, Körtik Tepe, Göbekli Tepe) through the tenth millennium $\mathrm{BC}$, and similar patterning is recorded during the ninth and eighth millennia at Boncuklu in the Konya plain of central Anatolia. Ongoing work at Aş1klı will clarify the equivalent period in Cappadocia. A third 'phase' can be recognised as consti- tuting cultivation of a range of crops undergoing domesti- cation and continued gathering of fruits and nuts. This third phase is evident in southeastern Anatolia by the middle of the ninth millennium BC, at sites such as Çayönü, Nevalı Çori and early Cafer Höyük, with equivalent data also from further south, such as those from Syria.

The emerging domestic crop spectrum of the mid ninth millennium cal. BC was combined with variable forms of animal husbandry: herding of sheep and goat in both central and southeast/eastern Anatolia, plus pig-keeping in the latter region (Peters et al. 2013; Stiner et al. 2014; Baird et al. 
forthcoming). Recent zooarchaeological results from late ninth-millennium cal. BC Aşıkl show the beginnings of a trend towards sheep-oriented husbandry that continued in central Anatolia through the later Pre-Pottery Neolithic and Pottery Neolithic (Stiner et al. 2014), with ovicaprid dietary evidence at Boncuklu suggesting contemporary experiments with husbandry (Middleton 2014; Baird et al. forthcoming). The complementarity of crops and livestock encom- passes not only the nutritional benefits of combining carbohydrate- and protein-rich foods, but also complemen- tary forms of storage (long shelf-life vs social storage: Bogaard et al. 2009) and ecological affordances (foddering, manuring etc: Bogaard 2005). Moreover, the emergence of distinctive domesticated crop varieties, and behavioural and morphological changes in animals, would have reinforced bonds between farming households investing in the perpetuation and protection of viable populations of local crop and livestock strains. This is the context of the large, long-lived tell communities that developed at Aşıklı and, later, Çatalhöyük.

In terms of early crops under cultivation and variously under domestication, regional differences are becoming apparent (table 1). In southeast/eastern Turkey, several glume (or hulled) wheats undergoing domestication - einkorn, emmer and probably the so-called 'new type' resembling Triticum timopheevi Zhuk (the latter termed 'machaoid type' in de Moulins 1997: 36-37, 53; see Jones et al. 2000) - emerge by the later ninth millennium cal. BC, but barley 9 appears morphologically wild until the later eighth millen- nium cal. BC and naked barley is absent. Intensive use of pulses is evident, as at Çayönü (van Zeist, de Roller 2003b). In central Anatolia, by the late eighth millennium BC, at Aceramic Çatalhöyük, the dominant cereals are the glume wheats (including the 'new type' - see below), naked barley and free-threshing (hexaploid) wheat, alongside a diverse range of pulses. Naked barley and free-threshing wheat are attested at Aşıklı by the eighth millennium cal. BC (table 1); ongoing work at Aşıkl and Boncuklu will shed further light on the earlier history of crop spectra in central Anatolia.

It is evident that different regional crop and livestock combinations had emerged by the end of the eighth millen- nium cal. BC in Anatolia. The establishment of mixed Neolithic farming 'packages' was thus a multi-centric process in western Asia, much like cultivation, herding and the eventual domestication of crops and animals (for example Fuller et al. 2011; Colledge et al. 2013; Willcox 2013). These mixed farming regimes launched dramati- cally new ways of life in western Asia and beyond (for example Bogaard 2005; Peters et al. 2005; Harris 2010).

\section{Çatalhöyük and the archaeobotanical dataset}

The double mound of Çatalhöyük (fig. 2) consists of a ca 13ha East Mound spanning the Aceramic to Ceramic Neolithic (late eighth millennium to late seventh millen- nium cal. BC, Early Central Anatolian IIIA-B: Özbaşaran, Buitenhuis 2002) and a ca 8ha West Mound, sited across the channel of the Çarşamba river, dating to the early Chal- colithic (early seventh millennium cal. BC). The archaeobotanical record currently available from the East Mound at Çatalhöyük is the product of 20 years of large-scale excavation and systematic sampling. Archaeobotanical sampling and recovery procedures are set out in Fairbairn et al. 2005, Hastorf 2005, Bogaard et al. 2013 and Filipović 2014. Multiple archaeobotanical datasets, each resulting from a distinct phase of analysis, are integrated here for the first time in order to develop a detailed under- standing of continuity and change in cropping practice and plant use through the sequence. A dataset of 62 archaeo- botanical samples from the early to middle Neolithic sequence in the South and North Areas of the East Mound, analysed by Fairbairn et al. 2005, is combined with 93 samples from the same sequence analysed by Filipović 2014, an additional acorn concentration reported by Hastorf 1996 and 318 samples from the middle to late Neolithic sequence presented by Bogaard et al. 2013 (we excluded the following due to contextual and/or chonological uncertainty: three samples from the KOPAL Area [Fairbairn et al. 2005], one from natural sediment in the South Area [Filipović 2014] and one unphased unit from the North Area [Bogaard et al. 2013]). Additionally, 31 samples analysed during the 2015 season to fill gaps in the 
South Area sequence (Bogaard et al. 2015) are included here, along with 80 samples from Jonathan Last and Catriona Gibson's 1998-2003 West Mound excavations, analysed by Charles and Bogaard in preparation, and 45 samples from Peter Biehl and Eva Rosenstock's excava- tions in Trench 5 on the West Mound, analysed by Stroud et al. in preparation. The term 'samples' includes some units of analysis comprising multiple similar amalgamated samples from the same deposit, as well as occasional distinct samples from the same excavation unit (see Bogaard et al. 2013; Filipović 2014). The resulting dataset consists of 630 samples (i.e. independent units of analysis representing distinct behavioural/depositional events). The deposits sampled are mostly mixed detritus of daily processing and consumption activities preserved in rake- outs from ovens and hearths, smeared onto adjacent 'dirty floors' and subsequently discarded in outdoor middens, but also include plant concentrations ('stores') preserved in burned buildings (Fairbairn et al. 2005; Bogaard et al. 2013; Filipović 2014). Burned-building assemblages dominate the data available from certain phases (table 2), and the effects of this are noted below in the presentation of the data.

Identification procedures for the charred plant remains from Çatalhöyük are set out in Bogaard et al. 2013: 94, fig. 7.2-7.5. Identification of cereal material included differ- entiation of the glume bases and grains of the so-called 'new type' glume (hulled) wheat from emmer and einkorn (Jones et al. 2000; Kohler-Schneider 2001) and also differ- entiation of two- and six-row naked barley rachis (the segmented stem within the ear) using new criteria presented by Charles et al. in preparation. Figure 3 illustrates the relevant anatomical components of glume (or hulled) and free-threshing wheats separated by threshing/subsequent dehusking and preserved by charring: grains, spikelet forks/glume bases of hulled wheats and rachis of free-threshing cereals. Barleys (whether naked or hulled) behave under processing like free-threshing wheat and are thus represented as grains and rachis segments.

Plant remains were quantified wherever possible by counting a 'minimum number of individuals' (mni) using diagnostic anatomical regions of cereal grains (apical and embryo ends), pulse seeds (embryo ends) and 'chaff' components (glume bases, upper parts of rachis internodes, culm nodes etc.: Bogaard et al. 2013: 94). For large fruit stones and nuts/nutshells, fragment counts were converted to mni estimates (Bogaard et al. 2013: 94). Andrew Fairbairn and colleagues (2005) quantified grains, nuts, etc using charred weight, and we have incorporated these conversions to mni estimates here. Since tuber material (parenchyma tissue) was not quantified for samples fully analysed ('Phase 3') in this study, it is not included here.

Table 2 gives a spatial and chronological summary of the archaeobotanical dataset discussed here, while figure 2 shows a plan of the site with all excavation areas mentioned in the text. The stratigraphic sequence currently documented in the South Area of the East Mound (South G through to South T) is the central 'spine' used in this paper; its Aceramic start date is modelled at around 7100 cal. BC (Bayliss et al. 2015). The end of the East Mound sequence, as documented in the TP Area, is modelled at around $5950 \mathrm{cal}$. BC (Marciniak et al. 2015), by which time the West Mound was already occupied, continuing to the mid sixth millennium cal. BC (Orton et al. in prepara- tion). The TP archaeobotanical data, covering the latest levels identified by James Mellaart in the 1960s, are still under study, and will be supplemented by ongoing analysis of the archaeobotany of the overlapping TPC sequence. Since the TP and TPC sequences are also not (yet) linked into the South Area sequence, here we discuss South G to South T, and the overlapping sequence of North F-I, leaving a 'gap' between South $\mathrm{T}$ and the West Mound. However, it is probable that a burned storeroom (Space 493) of a late Neolithic structure (Building 122) recently excavated in the TPC Area is equivalent to Mellaart III-IV (Marciniak et al. 2016). Another relatively late Neolithic burned structure is Building 63, excavated by the Istanbul team (Özbaşaran, Duru 2013), which corresponds to Mellaart IV-V. Though archaeobotanical data from these structures (Ergun et al. 2013; Bogaard et al. 2015) are not formally included here given their uncertain chronology and, in the case of Space 493 , because excavation and analysis are as yet incomplete, we will make strategic reference to crop 
stores in these two late Neolithic structures since they provide important corroborating evidence for the trends that emerge in the South Area and North Area sequences. Plant 'storage' concentrations in burned Buildings 79 and 80 in the South Area (South O) and Buildings 113 and 131 in the North Area (North F-G) are partially studied (Bogaard et al. 2015) and available data are included in this analysis. Table 2 indicates how burned building assemblages not or only partially included in the quantitative analysis fit chronologically and spatially alongside the central dataset analysed here. Provisional results from an analysis of plant remains recovered by Hans Helbaek during Mellaart's excavations of the 1960s are also included in the discus- sion below. The Mellaart archive derived from the later Neolithic occupation phases on the Çatalhöyük East Mound (table 2), and, while it represents sampling only of 'storage' concentrations in burned buildings, it usefully complements the broader sample set collected in recent decades.

\section{Results}

Table 3 summarises the occurrence of crops and gathered plants by level; the East Mound is represented by the South Area and North Area. Here, and in figures 4-6 and 10-13 below, adjacent levels represented by fewer than five samples have been amalgamated (for example South $\mathrm{H}$ and South I), as have levels yielding less than ten botanical items (of the categories under consideration). The diversity of pulses and cereals at the bottom of the tell, in South G, is especially high and this assemblage encompasses all of the crops that came to play a major role through the subse- quent East Mound sequence; only hulled barley arrived later, as sporadic grains through the mid to later Neolithic (Bogaard et al. 2013).

\section{Diachronic trends in cereal and pulse crops}

Figures 4 and 5 reveal two distinct changes through time in the forms of barley cultivated. An initial shift is apparent in the changing proportions of rachis types: two-row naked barley virtually replaced six-row naked by the mid Neolithic on the East Mound (fig. 4). Detection of this shift has relied on recent taxonomic work to clarify the morphological distinction between two- and six-row barley rachis across both naked and hulled forms (Charles et al. in preparation; cf. Bogaard et al. 2013). The shift from six- to two-row naked barley seems to have occurred around the same time in the South and North Areas of the settlement, and resulted in a clear predominance of two- row naked barley by South N and North G. Burned buildings of North G (Building 52) and South O (Building 80) have yielded 'storage' concentrations of what appear to be mostly or entirely two-row naked barley grains (i.e. well-preserved grains of the straight type, from the central spikelet, with few to no twisted/asymmetrical grains from lateral spikelets, as in the six-row form), as have later Neolithic Building 63 (IST Aea) and TPC's Building 122 (Space 493) (table 2; see also fig. 7). There are also large stores of naked barley grains in the late Neolithic levels (Buildings E.IV.4, A.III.4, A.II.1) of the Mellaart archive (table 2) - the plant assemblage studied by Helbaek (1964) from Mellaart's excavations of the $1960 \mathrm{~s}$ - that lack asymmetrical grains indicative of six-row barley. It appears, therefore, that the increasing preference for two- row naked barley involved its cultivation and storage as a 'pure' crop by the mid Neolithic sequence, with little to no admixture from the six-row form. Six-row naked barley increases in frequency on the West Mound but two- row barleys (now hulled as well as naked) remain dominant (figs 4 and 5). A plausible ecological motive for the shift from six- to two-row barley would be selection for enhanced drought-tolerance, to be discussed further below.

A second shift in barley forms occurs towards the end of the South Area sequence, when increasing proportions of hulled barley occur alongside the dominant form, naked barley: a change most readily identified in grain morphology (fig. 5). Hulled barley is currently first recorded in North F and South Q, and was a minor component through to South T; future work on the TP and 
TPC assemblages will determine whether or not hulled barley became dominant over naked barley prior to the occupation of the West Mound, but it is clear that TPC's burned storeroom Space 493 (table 2) contained naked barley stores. Two-row hulled barley is the dominant variety on the West Mound (figs 4 and 5; cf. Bogaard et al. 2013).

Figure 5 also shows other changes in cereal usage over time on the basis of cereal grain. Here we amalgamate different forms of glume wheat into a single category since criteria for differentiating 'new type' grain from emmer and einkorn (Kohler-Schneider 2001; Bogaard et al. 2013: fig. 7.3) were not readily available in earlier phases of work (we consider different forms of glume wheat on the basis of chaff below). There is a general trend towards decreasing glume wheat grain through time in favour of free-threshing wheat and barley. Wheats generally outnumber barley throughout the sequence. The occur- rence of burned buildings with in situ crop concentrations creates discrepancies among South $\mathrm{O}$ and North $\mathrm{F}-\mathrm{G}$, but both areas of the settlement follow a general trend away from a predominance of glume wheats and towards a more even balance with free-threshing wheats and barley. This shift is reversed on the West Mound.

Figure 6 summarises changing cereal proportions through time on the basis of chaff. The dominance of glume wheat glume bases more or less throughout the sequence reflects frequent dehusking of grain stored in spikelet form (grains enclosed by glumes: see fig. 3), in contrast to barley and free-threshing wheat, which appear to have been threshed and winnowed off-site following the harvest and stored as (semi-) clean grain, with only late processing stages (such as fine sieving) routinely taking place on-site (Fairbairn et al. 2005; Bogaard et al. 2013). Figure 6 reveals a clear mid-sequence shift in the relative importance of emmer versus 'new type' glume wheat: in the South Area sequence, emmer is the dominant form until South $\mathrm{N}-\mathrm{O}$, but it is minor in comparison to the 'new type' in South P through to T. In the North Area sequence, the 'new type' is the dominant glume wheat form in North F-G: distinctly earlier than in the South Area sequence. By South P and North $\mathrm{H}$, the 'new type' is similarly dominant over emmer in both areas. Emmer occurs at slightly higher levels in the West Mound, but the 'new type' remains dominant. Einkorn, a third glume wheat type, occurs in minor proportions throughout the sequence, though einkorn grain features in a probable store in Mellaart's building A.II.1 and made up most of the fill of storage bin 7 in House E.VI.17 (table 2).

qFurther insight into this shift is provided by variation in the occurrence of one or the other crop as 'storage' deposits in burned buildings of the mid Neolithic sequence (South O, North F-G: fig. 7). In the North Area, pure 'storage' concentrations of 'new type' spikelets occur in burned Building 77 (North G: Bogaard et al. 2013) and in an earlier neighbouring burned building, assigned to North F, Building 131 (table 2, figs 7a, 8; Bogaard et al. 2015). In the South Area, Mellaart's excavations yielded two known concentrations of 'new type' glume wheat, originally identified as emmer by Helbaek and currently under analysis by Fairbairn. One of these is from a building (E.VI.1: Mellaart 1962: fig 7) that could be from VIA (South O) or VIB (South N); the second 'new type' glume wheat concentration is labelled A.VI.3, probably corre- sponding to what Mellaart later called E.VI.63 (Mellaart 1964: figs 1-2). By contrast, burned Building 79 in the South Area (table 2, fig. 7b), excavated in 2009 (Eddisford 2009), has yielded 'pure' deposits of emmer, also stored as spikelets (fig. 9), alongside free-threshing wheat grain, but no 'new type' (fig. 7b). While Building 131 and Building 79 are still under study, two inferences appear justified from the available evidence. First, 'new type' and emmer were stored and likely also grown separately, as distinct crops. Secondly, burned buildings of the mid Neolithic sequence have yielded concentrations of one or the other glume wheat, reflecting possible contrasts in social geography that require further study. Rather than an increasing proportion of 'new type' over emmer in a mixed/maslin crop (cf. Jones, Halstead 
1995), therefore, 'new type' was grown and stored separately to emmer, and the shift in preference represents a conscious innovation, perhaps initially in the North Area of the settlement. The only glume-wheat concentration excavated so far from a later Neolithic building, the burned storeroom (Space 493) of TPC's Building 122 (table 2), has yielded a large, pure concentration of 'new type' spikelets (Fuller et al. 2014), currently under study.

Figure 10 summarises proportions of pulses through time, and reveals another mid-Neolithic shift, from lentil to pea, approximately parallel to the shift from emmer to 'new type'. Burned buildings of the mid Neolithic in both the South $(\mathrm{O})$ and North $(\mathrm{F}-\mathrm{G})$ Areas provide multiple instances of 'storage' concentrations of (predominantly) lentil or pea (fig. 7), which, like those of emmer and the 'new type' glume wheat, clearly reflect contrasting crop choices and potential social geographical patterning. Following these burned building horizons, the shift from lentil to pea is clear by South (P) and North (H-I), but is reversed on the West Mound: another contrast with trends observed on the East Mound. It is notable that the earliest burned building in the North Area - Building 131 - yielded a pea concentration, suggesting an early focus on this crop, while Building 1 (North G) yielded a large lentil deposit, indicating continued interest in this pulse by some house- holds in the same neighbourhood (fig. 7a).

Other diachronic changes in the pulse spectrum include the sporadic occurrence of grass pea and chickpea after South G (table 3; Bogaard et al. 2013: table 7.3) and a tendency towards lower proportions of bitter vetch through time (fig. 10). Pulse concentrations in Mellaart's archive (table 2) include several of pea (E.VI.25, E.V.8, E.IV, A.II.1), one of bitter vetch (E.VI.14/17) and a unique deposit of grass pea (A.VI.1). The dominance of lentil and/or pea in most phases and the reduction in bitter vetch through time may reflect a general preference for pulses lacking concentrations of toxins in the testa (outer seed coat) that must be removed by soaking, leaching, etc. in order to avoid detrimental effects on human health (cf. Valamoti 2009). This preference could be analogous to the observed decrease in the usage of glume wheats - which are more labour-intensive to process than free-threshing wheat and naked barley - through time (above, fig. 5).

\section{Crops and gathered plants}

Figure 11 summarises ubiquities of cereal, pulse, small- seeded mustard (mostly Descurainia sophia, an oil-seed plant, possibly cultivated: Fairbairn et al. 2007; Bogaard et al. 2013) and fruit/nut taxa through time. Lower ubiq- uities of all categories in the mid and later Neolithic levels are at least partly an artefact of the deposit types repre- sented: the proliferation of fire spots in the mid to later Isequence (especially South P) dominated by non-food (dung-derived) plants and the occurrence of burned buildings (South $\mathrm{O}$ and North $\mathrm{F}-\mathrm{G}$ ) with separate stores of cereals, pulses and collected plants (Bogaard et al. 2013). By contrast, the samples analysed from both the earlier Neolithic sequence and the West Mound are dominated by middens and other 'mixed' deposits in which all categories tend to be ubiquitous (Fairbairn et al. 2005; Filipović 2014; Charles, Bogaard in preparation; Stroud et al. in preparation). Figure 12a-b summarises percentages of cereal grain, cereal chaff, pulse, mustard and fruit/nut material through time; figure $12 \mathrm{c}-\mathrm{d}$ shows percentages excluding wild mustard, whose small seeds are very numerous in certain 'storage' deposits and hence swamp some phases shown in figure $12 \mathrm{a}-\mathrm{b}$. The dominance of cereals in most levels reflects the abundance of preserved chaff; high proportions of cereal grain in South $\mathrm{O}$ and North F, and of pulses (and mustard) in North G, reflect the prevalence of storage deposits from burned buildings in these levels (Fairbairn et al. 2005; Bogaard et al. 2013; Filipović 2014). There is a slight tendency for pulse proportions to decrease through time in the earlier Neolithic levels, and for fruit/nut proportions to increase through the South Area sequence, but the clearest obser- vation is that cereals remain dominant, accompanied throughout by minor proportions of pulse and fruit/nut. 
Finally, we consider trends in the occurrence of fruits and nuts from perennial trees and shrubs. Though these resources are often referred to as 'wild', they were likely subject to management and protection, like the annual crops dealt with above. As noted earlier, sedge tubers were not fully quantified in all the available datasets, and so are not included here. The tubers (and nutlets) of sedges, espe- cially Bolboschoenus glaucus, are ubiquitous throughout the sequence. The nutlets are at least partly derived from the burning of animal dung as fuel (Bogaard et al. 2013), while the tubers may have been collected as food, as a few examples have been found embedded in cereal-based, bread-like food remains (Gonzalez Carretero et al. 2017), and were probably consumed fresh, given their absence from 'storage' deposits (Fairbairn et al. 2005; Bogaard et al. 2013). Figure 13 summarises proportions of fruit/nut taxa through time, revealing continuity in use of hackberry (preserved in the absence of charring due to its silica-rich shell) and pistachio. Poorly preserved nut shell/fruit stone identified as 'almond/plum' is attested more or less throughout the sequence, sometimes alongside better- preserved remains mostly identifiable as almond (rela- tively few plum stones have been observed, and are included here with 'almond/plum').

There is a notable decrease in acorn from South $\mathrm{P}$ onwards that coincides with a replacement of oak by juniper as the dominant fuel wood species (Asouti 2013). Though the fragile shell of acorn is never very abundant, a burned building of North G (Building 1) contained a cluster of ca 40 whole acorns in a side room (Hastorf 1996), whereas a nearby burned structure (Building 52) yielded a cache of whole almonds from one of its clay bins (fig. 7; Bogaard et al. 2013), accounting for unusually high proportions in that phase (fig. 13). It is possible that these differences in nut storage reflect social geographical patterning, parallel to the different crop distributions in these and other burned structures (fig. 7a). The Mellaart archive (table 2) has yielded several acorn concentrations from burned buildings (A.VI.1, A.VI.4, E.VI.1), all belonging to Mellaart's Level VI (South N-O).

The 'other' fruit/nut category is dominated by fig seeds (fig. 14), which occur sporadically throughout the sequence from South G onwards (Bogaard et al. 2013: table 7.3) and are relatively abundant in South T (Building 44: Regan, Taylor 2014). The restricted occurrence of fig seeds generally at Çatalhöyük contrasts notably with their presence at Neolithic sites in Greece such as sixth-millen- nium Halai (East Lokris), where the charred flesh and seeds of fig are ubiquitous, pointing to drying/storage and frequent consumption (fig. 14c; Diffey and Bogaard in preparation). Fig wood identifiable as Ficus carica is attested at Çatalhöyük but at very low levels (Asouti 2013: table 8.2-3). Trees of the Mediterranean Ficus carica complex can be observed in riverine settings today throughout semi-arid southwestern Asia, including south- central Turkey (Davis et al. 1965).

व

\section{qDiscussion}

Recent stable carbon isotope analysis of crop remains from the East Mound of Çatalhöyük (Wallace et al. 2015) has shown that barley was grown under drier conditions than wheats, likely due to greater drought tolerance (cf. Riehl 2009). Modern two-row barley has higher water use effi- ciency than sixrow barley, meaning that it is better yielding in droughted environments, while six-row barley is better yielding in well-watered conditions (Voltas et al. 1999; Jiang et al. 2006; Aniya et al. 2007). The inherent repro- ductive superiority of six-row barley means that shifts towards two-row barley, as documented at Çatalhöyük, require strong selection for two-row barley, either through cultural practices or ecological conditions (Palmer et al. 2009). It is plausible that Çatalhöyük cultivators valued the greater drought tolerance of two-row barley over the six- row form, and that they increasingly selected two-row naked barley for strategic planting in the drier parts of the arable landscape through time. The local landscape offered a very variable set of niches for crops, ranging 
from dry marl hummocks to better-watered areas on the margins of seasonal flooding (Charles et al. 2014; Ayala et al. orthcoming). Moreover, while regional pollen records suggest that precipitation was generally higher during the Neolithic than today (Charles et al. 2014), variability in rainfall in this semi-arid zone would have threatened crop yields from one year to the next. Stable carbon isotope analysis of crops from multiple Neolithic to Bronze Age sites in western Asia and the eastern Mediterranean has shown that crop growing conditions at Neolithic Çatalhöyük were, if anything, relatively water-limited (Wallace et al. 2015). There is evidence of increasing dryness around 8.2 kya in central Turkey from recent lake geochemistry (Dean et al. 2015; Roberts et al. 2016) and in the local landscape from specific hydrogen isotope analysis of lipid residues in cooking pots (Pitter et al. 2013). Selection of a more drought-tolerant form of barley was likely a key Neolithic adaptation to such condi- tions, and may have played a particular role in resilience through phases of greater aridity such as the 8.2 kya event (Flohr et al. 2016). Ongoing stable isotope analysis of hulled barley from the TP Area and the West Mound (Stroud, Bogaard in preparation) will reveal whether or not this crop, like naked barley, was preferentially grown under drier conditions than wheats.

TWheats generally remained dominant throughout the East Mound sequence (fig. 5), and were planted in better- watered parts of the landscape (Wallace et al. 2015). The general trend from glume (hulled) to free-threshing wheat through time (fig. 5) may reflect a better yield response in relatively well-watered soils, or at least an interest in diver- sifying this better-watered niche. It could also reflect an increasing interest in growing crops that were processed off-site, immediately following the harvest, and stored in cleaned form, as opposed to piecemeal processing (i.e. dehusking of glume wheat spikelets) at the household level throughout the year. Increasing interest in ease of processing may also explain the decrease in bitter vetch in favour of less toxic pulses through time (fig. 10). This increasing preference for less labour-intensive crop processing through the East Mound sequence coincides with a diversification of other activities demanding space within the house (Hodder 2014c). On the West Mound, however, this trend is reversed, with a preference for hulled over naked barley and glume wheats over free- threshing wheat (fig. 6).

The shift from emmer to 'new type' glume (hulled) wheat presents a clear instance of a crop innovation that was initially taken up by some households and not others. Currently, the earliest evidence for a 'pure' cache of 'new type' glume wheat spikelets occurs in Building 131 of the North Area; the storage deposits in the later neighbouring structure, Building 77 (North G), appear to confirm the perpetuation of this tradition of cultivating the 'new type' glume wheat rather than emmer (figs 7, 8). By contrast, emmer deposits in burned Building 79 (South O), for example, suggest that some households continued to favour this crop. In resilience-theory terms (Holling 2001), the important point is not so much which house(s) or part(s) of the settlement were the chief innovators, but rather that such innovations were rooted in some house- holds and not others. The implication is that certain house- holds were 'incubators' of new potential staples, meaning that the risks of such innovation were confined to small- scale social groups (cf. Holling 2001: 397). In the case of the 'new type', this form of glume wheat was eventually adopted as the preferred glume wheat species across the community, presumably because it proved to be a hardy crop that coped well with the local environment and suited the evolving culinary tradition.

Multiple innovations in resource use at Çatalhöyük cluster in the mid Neolithic sequence and were widely adopted just after the community had attained its maximum size - variously estimated in the low thousands at least (Cessford 2005; cf. Bogaard forthcoming) - in the mid seventh millennium BC, around South M-O/North G (table 2), when it showed signs of reorganisation (Hodder 2014c). Shifts in subsistence practice, established by South, include that from emmer to 'new type' glume wheat, the change from lentils to peas, the choice of juniper over oak as wood fuel (Asouti 2013), increased sheep consumption, smaller scale herding at the subcommunity level and cattle herding (Russell et al. 2013). 
These changes parallel a staggered series of changes in material culture that reflect reorganisation of household activities, including a shift from clay-ball 'boilers' to cooking pots, the development of external activity areas ('yards') including ovens and increased use of stamp seals (Atalay, Hastorf 2006; Bogaard et al. 2014).

One way to understand these clustered adjustments is the perspective of panarchy theory (Gunderson, Holling 2001; Holling 2001), which predicts that innovations will escalate under conditions of ecological uncertainty and also that complex social obligations may limit flexibility and lead to a 'rigidity trap' that can only be overcome through significant reorganisation. At Çatalhöyük, climatic variability was coupled with the internal pressure of the community's increasing fertility and population size in the middle Neolithic sequence (cf. Hillson et al. 2013). It is plausible that many of the innovations in cropping practice emerged as 'experiments' on the part of particular house- holds or neighbourhoods, which acted as testing grounds for new patterns of behaviour that might or might not prove successful enough to be adopted across the community as a whole. A similar pattern of behaviour has been observed in changing mudbrick sources through time, with particular houses anticipating the subsequent, wider shift to new materials (Love 2013). Though some panar- chies are hierarchical, many are not (Gunderson, Holling 2001), and Çatalhöyük's 'aggressively egalitarian' community (Hodder 2014a) facilitated permeability and the transfer of successful innovations among individuals, households and neighbourhoods.

The long-term sustainability of Çatalhöyük thus appears to have depended on several factors that enabled flexible strategies over time. First, the founders of the community brought with them a wide range of cereal and pulse crops, as well as a tradition of diversified plant management and collection. While certain cereals and pulses were initially favoured, other taxa persisted as minor crops or contaminants, lingering to be recruited later as staples by individuals and households interested in developing new crops and tastes. Second, while land tenure was likely organised at the suprahousehold level, perhaps in radial 'wedges' allocated to particular neighbourhoods (cf. Charles et al. 2014; Hodder 2014b; Bogaard forthcoming) and acknowledging territorial inheritance from founder settlements (Fairbairn 2005), individual households appear to have made contrasting choices of which crops to sow, with particular variation amongst glume wheats and pulses around the mid Neolithic sequence. That such decision-making took place at a small social scale - the individual household or house group perhaps - was ecologically crucial, because the risks of growing pure stands of minor crops were thus contained. While it could be argued that (deliberately) burned houses reflect a more complex choreography, the fact that different crop species occur in different houses plausibly reflects similarly scaled agency (for example the 'new type' glume wheat deposited in Building 77 [fig. 7a] was not necessarily chosen/grown by its inhabitants, but clearly was chosen by another affiliated household/s). A third factor was perme- ability across co-residential groups, enabling pure seed corn of unusual crops, collected by certain innovating house- holds, to be dispersed more widely.

While resilience theory usefully frames consideration of Çatalhöyük's persistence as a community, it does not of course account for the whole story of crop change. The developments in cropping described here concern not only growing conditions and field ecology but also cooking and culinary traditions. Closely related crops with similar generic uses can have subtly different cooking properties; variable preferences for einkorn or emmer in present-day Kastamonu, for example, are reportedly based on prefer- ences for different grain qualities in bulgur production (Ertuğ 2004). It is thus plausible that changing cropping strategies at Çatalhöyük - including variation amongst contemporary households (fig. 7) - fostered different tastes and identities. Study of charred amorphous fragments of foodstuffs indicates the preparation of batters and breads throughout the East Mound sequence but with increasing preparations of cereal-based porridges in the latest (TP/TPC) levels (Gonzalez Carretero et al. 2017). Diachronic trends also imply changing priorities in the organisation of daily tasks, with less time devoted to frequent, labour-intensive processing activities such as 
soaking the toxins from bitter vetch seeds or dehusking glume wheats.

\section{Conclusions}

The long-term archaeobotanical record of Neolithic to early Chalcolithic Çatalhöyük affords unusual insights into processes of early agricultural innovation among households and over time. Rather than maintaining a fixed set of crops requiring stable ecological and social conditions, the diverse agroecology of Çatalhöyük enabled generations of cultiva- tors to maintain flexible cropping strategies as part of a changing landscape. Panarchy theory provides a useful way of understanding the inseparability of social and environ- mental conditions in shaping long-term resilience and sustainability. Çatalhöyük's persistence was just as dependent on its social morphology as on the genetic/ecolog- ical potential of the crops with which it was founded.

Such case studies offer a useful perspective on so- called 'boom-and-bust' cycles in the western European Neolithic (for example Downey et al. 2016). While apparent demographic 'bust' events have naturally received the most attention, unpicking the complex causality of such cycles relies on detailed documentation of strategies that were successful over the long-term, as at Çatalhöyük. Moreover, very long-term prehistoric farming sequences can and should inform wider agroecological understanding of sustainable development, in present-day Anatolia and beyond, as dependent upon a diverse reper- toire of crops, an active 'archive' of cropping potential in the form of minor crops and weedy contaminants, and a nested set of permeable social scales. These potentials are currently threatened inter alia by the dominance of 'elite' commercial crop varieties demanding uniform, high-input conditions, centralised, top-down agricultural management and restrictions on the movement and exchange of seed corn from traditional landraces.

\section{Acknowledgements}

We thank the Çatalhöyük Research Project and its director, Ian Hodder, for making this work possible. We thank anonymous reviewers for their feedback, which strength- ened this paper. Ian Hodder and Ceren Kabukcu provided useful criticism of an earlier draft, while Alex Bayliss and Shahina Farid provided information on Mellaart's buildings and Camilla Mazzucato carried out GIS mapping. This work was funded by the John Templeton Foundation (grant no. 13463, 22893, 52003; PI Hodder); the Polish National Science Centre (Harmonia research grant, decision DEC2012/06/M/H3/00286; PI Marciniak); the Polish Ministry of Science and Higher Education (grant no. 3085/ Kultura/2014/2); the British Institute at Ankara; the Wenner Gren Foundation (grant no. 6924; PI Fairbairn); the Australian Research Council (FT130101702; CI Fairbairn); the 'ComPAg' Project (European Research Council grant no. 323842, PI Fuller); and the 'AGRICURB' Project (European Research Council grant no. 312785, PI Bogaard).

\section{References}

\Anyia, A., Slaski, J., Nyachiro, J., Archambault, D., Juskiw, P. 2007: 'Relationship of carbon isotope discrimination to water use efficiency and productivity of barley under field and greenhouse conditions' Journal of Agronomy and Crop Science 193: 313-23. https://doi.org/10.1111/j.1439037X.2007.00274.X

Asouti, E. 2013: 'Woodland vegetation, firewood management and woodcrafts at Çatalhöyük' in I. Hodder (ed.), Humans and Landscapes of Çatalhöyük: Reports from the 2000-2008 Seasons. Los Angeles/London, Cotsen Institute of Archaeology/British Institute at Ankara: 129-61

Atalay, S., Hastorf, C.A. 2006: 'Food, meals, and daily activities: food habitus at Neolithic Çatalhöyük’ American Antiquity 71: 283-319. https://doi.org/10.2307/40035906

Ayala, G., Wainwright, J., Walker, J., Hodara, R., Lloyd, J., Leng, M., Doherty, C. forthcoming: 
'Palaeoenvironmental reconstruction of the alluvial landscape of Neolithic Çatalhöyük, central southern Turkey: the implications for early agriculture and responses to environmental change' Journal of Archaeological Science

Baird, D., Fairbairn, A., Jenkins, E., Martin, L., Middleton, C., Pearson, J., Asouti, E., Edwards, Y., Kabukcu, C., Mustafaoğlu, G., Russell, N., Bar-Yosef, O., Jacobsen, G., Wu, X. forthcoming: 'Agricultural origins on the Anatolian plateau'

Baird, D., Fairbairn, A., Martin, L., Middleton, C. 2012: 'The Boncuklu project: the origins of sedentism, cultivation and herding in central Anatolia' in M. Özdoğan, N. Başgelen, P. Kuniholm (eds), The Neolithic in Turkey 3. Central Turkey. Istanbul, Arkeoloji ve Sanat Yayınları: 219-44

Bayliss, A., Brock, F., Farid, S., Hodder, I., Southon, J., Taylor, R.E. 2015: 'Getting to the bottom of it all: a Bayesian approach to dating the start of Çatalhöyük' Journal of World Prehistory 28: 1-26. https://doi.org/10.1007/s10963- 015-9083-7

Bayliss, A., Farid, S., Higham, T. 2014: 'Time will tell: practicing Bayesian chronological modeling on the East Mound' in I. Hodder (ed.) Çatalhöyük Excavations: The 2000-2008 Seasons. Los Angeles/London, Cotsen Institute of Archaeology/British Institute at Ankara: 53-90

Bogaard, A. 2005: "“Garden agriculture" and the nature of early farming in Europe and the Near East' World Archaeology

37: 177-96. https://doi.org/10.1080/00438240500094572

— forthcoming: 'Neolithic "cooperatives": assessing supra-household cooperation in crop production at Çatalhöyük and beyond' in M. Benz, H.-G.K. Gebel (eds), The Construction of Neolithic Corporate Identities (ICAANE Workshop Basel, June 9-10 2014). Berlin, ex oriente

Bogaard, A., Charles, M., Livarda, A., Ergun, M., Filipović, D., Jones, G. 2013: 'The archaeobotany of mid-later Neolithic occupation levels at Çatalhöyük' in I. Hodder (ed.), Humans and Landscapes of Çatalhöyük: Reports from the 2000-2008 Seasons. Los Angeles/London, Cotsen Institute of Archaeology/British Institute at Ankara: 93-128

Bogaard, A., Charles, M., Twiss, K.C., Fairbairn, A., Yalman, N., Filipović, D., Demirergi, G.A., Ertuğ, F., Russell, N., Henecke, J. 2009: 'Private pantries and celebrated surplus: storing and sharing food at Neolithic Çatalhöyük’ Antiquity 83: 649-68. https://doi.org/10.1017/S0003598X00098896

Bogaard, A., Fuller, D.Q., Charles, M., Filipović, D. 2015: 'Botanical archive report 2015' in Çatalhöyük 2015 Archive Report. http://www.catalhoyuk.com/archive_reports/2015

Bogaard, A., Ryan, P., Yalman, N., Asouti, E., Twiss, K.C., Mazzucato, C., Farid, S. 2014: 'Assessing outdoor activities and their social implications at Çatalhöyük' in I. Hodder (ed.), Integrating Çatalhöyük: Themes from the 2000-2008 Seasons. Los Angeles/London, Cotsen Institute of Archaeology/British Institute at Ankara: 123-47

Carter, T., Milić, M. 2013: 'The chipped stone' in I. Hodder (ed.), Substantive Technologies at Çatalhöyük: Reports from the 2000-2008 Seasons. Los Angeles/London, Cotsen Institute of Archaeology/British Institute at Ankara: 417-78

Cessford, C. 2005: 'Estimating the Neolithic population of Çatalhöyük' in I. Hodder (ed.), Inhabiting Çatalhöyük: Reports from the 1995-1999 Seasons. Cambridge/London, McDonald Institute for Archaeological Research/British Institute at Ankara: 323-26

Charles, M., Bogaard, A. in preparation: 'The archaeobotany of the West Mound excavations, 19982003'

Charles, M., Doherty, C., Asouti, E., Bogaard, A., Henton, E., Spencer Larsen, C., Ruff, C.B., Ryan, P., Sadvari, J.W., Twiss, K.C. 2014: 'Landscape and taskscape at Çatalhöyük: an integrated perspective' in I. Hodder (ed.), Integrating Çatalhöyük: Themes from the 2000-2008 Seasons. Los Angeles/London, Cotsen Institute of Archaeology/British Institute at Ankara: 71-90

Charles, M., Filipović, D., Bogaard, A. in preparation: 'New criteria for distinguishing the rachis morphology of different barley varieties' 
Colledge, S., Conolly, J., Dobney, K., Manning, K., Shennan, S. (eds) 2013: The Origins and Spread of Domestic Animals in Southwest Asia and Europe. Walnut Creek, Left Coast Press

Davis, P.H., Cullen, J., Coode, M.J.E. 1965: Flora of Turkey and the East Aegean Islands 7. Edinburgh, Edinburgh University Press

de Moulins, D. 1997: Agricultural Changes at Euphrates and Steppe Sites in the mid-8th to the 6th Millennium BC. Oxford, Archaeopress

Dean, J.R., Jones, M.D., Leng, M.L., Noble, S.R., Metcalfe, S.E., Sloane, H.J., Sahy, D., Eastwood, W.J., Roberts, C.N. 2015: 'Eastern Mediterranean hydroclimate over the late glacial and Holocene, reconstructed from the sediments of Nar lake, central Turkey, using stable isotopes and carbonate $\begin{array}{llllll}\text { mineralogy' } & \text { Quaternary } & \text { Science } & \text { Reviews } & 124: & 162-\end{array}$ https://doi.org/10.1016/j.quascirev.2015.07.023

Diffey, C., Bogaard, A. in preparation: 'The archaeobotany of Neolithic Halai, East Lokris, Greece'

Downey, S.S., Haas Jr, W.R., Shennan, S.J. 2016: 'European Neolithic societies showed early warning signals of popu- lation collapse' Proceedings of the National Academy of Sciences 113: 9751-56. https://doi.org/10.1073/pnas.1602504113

Eddisford, D. 2009: 'Building 79' in Çatalhöyük 2009 Archive Report. http://www.catalhoyuk.com/archive_reports/2009 Ergun, M., Bogaard, A., Charles, M. 2013: 'The archaeobotany of the IST Area' in I. Hodder (ed.), Excavating Çatal- höyük: The 2000-2008 Seasons. Los Angeles/London, Cotsen Institute of Archaeology/British Institute at Ankara: 655-57

Ertuğ, F. 2004: 'Recipes of old tastes with einkorn and emmer wheat' TÜBA-AR 7: 177-88. http://dx.doi.org/10.22520/tubaar.2004.0014

Fairbairn, A.S. 2005: 'A history of agricultural production at Çatalhöyük East, Turkey' World Archaeology 37: 197- 210 https://doi.org/10.1080/00438240500094762

Fairbairn, A., Hillman, G. forthcoming: 'Aceramic Neolithic and Ottoman archaeobotany at Canhasan III, Karaman, central Turkey’ Vegetation History and Archaeobotany

Fairbairn, A.S., Jenkins, E., Baird, D., Jacobsen, G. 2014: 'Ninth millennium plant subsistence in the central Anatolian highlands: new evidence from Pinarbaşi, Karaman province, central Anatolia' Journal of Archaeological Science 41: 801-12. https://doi.org/10.1016/j.jas.2013.09.024

Fairbairn, A.S., Martinoli, D., Butler, A. Hillman, G. 2007: 'Wild plant seed storage at Neolithic Catalhoyuk East, Turkey' Vegetation History and Archaeobotany 16: 467-79. https://doi.org/10.1007/s00334-006-0069-3

Fairbairn, A.S., Near, J., Martinoli, D. 2005: 'Macrobotanical investigation of the North, South and KOPAL Area exca- vations at Çatalhöyük East' in I. Hodder (ed.), Inhabiting Çatalhöyük: Reports from the 1995-1999 Seasons. Cambridge/London, McDonald Institute for Archaeological Research/British Institute at Ankara: 137-201

Filipović, D. 2014: Early Farming in Central Anatolia: An Archaeobotanical Study of Crop Husbandry, Animal Diet and Land use at Neolithic Çatalhöyük. Oxford, Archaeopress

Flohr, P., Fleitmann, D., Matthews, R., Matthews, W., Black, S. 2016: 'Evidence of resilience to past climate change in Southwest Asia: early farming communities and the 9.2 and 8.2 ka events' Quaternary Science Reviews 136: 23-39. https://doi.org/10.1016/j.quascirev.2015.06.022

French, D.H., Hillman, G.C., Payne, S., Payne, R.J. 1972: 'Excavations at Can Hasan III 1969-70' in E.S. Higgs (ed.), Papers in Economic Prehistory. Cambridge: Cambridge University Press: 181-90

Fuller, D., Bogaard, A., Charles, M., Filipović, D. 2014: 'Botanical archive report 2013' in Çatalhöyük 2014 Archive Report. http://www.catalhoyuk.com/archive_reports/2014

Fuller, D.Q., Willcox, G., Allaby, R.G. 2011: 'Cultivation and domestication had multiple origins: arguments against the core area hypothesis for the origins of agriculture in the Near East' World Archaeology 43: 628-52. https://doi.org/10.1080/00438243.2011.624747

Gonzalez Carretero, L., Wollstonecroft, M., Fuller, D.Q. 2017: 'A methodological approach to the study of 
archaeological cereal meals: a case study at Çatalhöyük East (Turkey)' Vegetation History and Archaeobotany 26: 415-32. https://doi.org/10.1007/s00334-017-0602-6

Gunderson, L.H., Holling, C.S. 2001: Panarchy: Understanding Transformations in Human and Natural Systems. Wash- ington DC, Island Press

Harris, D.R. (ed.) 2010: Excavations at Jeitun. Philadelphia, University of Pennsylvania

Museum Press Hastorf, C. 1996: 'Botanical archive report 1996' Çatalhöyük 1996

Archive Report.

http://www.catalhoyuk.com:8080/archive_reports/1996/ar96_13.html

— 2005: 'Macrobotanical investigation: field methods and laboratory analysis procedures' in I. Hodder (ed.), Inhabiting Çatalhöyük: Reports from the 1995-1999 Seasons. Cambridge/London, McDonald Institute for Archaeological Research/British Institute at Ankara: 129-35

Helbaek, H. 1964: 'First impressions of the Çatal Hüyük plant husbandry' Anatolian Studies 14: 12123. https://doi.org/10.2307/3642467

Hillson, S., Larsen, C.S., Boz, B., Pilloud, M.A., Sadvari, J.W., Agarwal, S.C., Glencross, B., Beauchesne, P., Pearson, J.A., Ruff, C.B., Garofalo, E.M., Hager, L.D., Haddow, S.D. 2013: 'The human remains I: interpreting community structure, health and diet in Neolithic Çatalhöyük' in I. Hodder (ed.), Humans and Landscapes of Çatalhöyük: Reports from the 2000-2008 Seasons. Los Angeles/London, Cotsen Institute of Archaeology/British Institute at Ankara: 339-96

Hodder, I. 2014a: 'Çatalhöyük: the leopard changes its spots. A summary of recent work' Anatolian Studies 64: 1-22. https://doi.org/10.1017/S0066154614000027

- 2014b: 'Mosaics and networks: the social geography of Çatalhöyük' in I. Hodder (ed.), Integrating Çatalhöyük: Themes from the 2000-2008 Seasons. Los Angeles/London, Cotsen Institute of Archaeology/British Institute at Ankara: 149-67

- 2014c: 'Temporal trends: the shapes and narratives of cultural change at Çatalhöyük' in I. Hodder (ed.), Integrating Çatalhöyük: Themes from the 2000-2008 Seasons. Los Angeles/London, Cotsen Institute of Archaeology/British Institute at Ankara: 169-84

Holling, C.S. 1973: 'Resilience and stability of ecological systems' Annual Review of Ecology and Systematics 4: 1-23. https://doi.org/10.1146/annurev.es.04.110173.000245

- 2001: 'Understanding the complexity of economic, ecological, and social systems' Ecosystems 4: 390-405. https://doi.org/10.1007/s10021-001-0101-5

Hütteroth, W.-D., Höhfeld, V. 2002: Türkei. Darmstadt, Wissenschaftliche Buchgesellschaft

Jiang, Q., Roche, D., Hole, D. 2006: 'Carbon isotope discrimination of two-rowed and six-rowed barley genotypes under irrigated and non-irrigated field conditions' Canadian Journal of Plant Science 86: 433-41. https://doi.org/10.4141/P05-217

Jones, G., Halstead, P. 1995: 'Maslins, mixtures and monocrops: on the interpretation of archaeobotanical crop samples of heterogeneous composition' Journal of Archaeological Science 22: 103-14. https://doi.org/10.1016/S0305- 4403(95)80168-5

Jones, G., Valamoti, S., Charles, M. 2000: 'Early crop diversity: a "new” glume wheat from northern Greece' Vegetation History and Archaeobotany 9: 133-46. https://doi.org/10.1007/BF01299798

Kohler-Schneider, M. 2001: Verkohlte Kultur- und Wildpflanzen aus Stillfried an der March als Spiegel spät- bronzezeitlicher Landwirtschaft im Weinviertel. Vienna, Verlag der Österreichischen Akademie der Wissenschaften Love, S. 2013: 'An archaeology of mudbrick houses from Çatalhöyük' in Hodder (ed.), Substantive Technologies at Çatalhöyük: Reports from the 2000-2008 Seasons. Los Angeles/London, Cotsen Institute of Archaeology/British Institute at Ankara: 81-96

Marciniak, A., Barański, M.Z., Bayliss, A., Czerniak, L., Goslar, T., Southon, J., Taylor, R.E. 2015: 'Fragmenting times: interpreting a Bayesian chronology for the late Neolithic occupation of Çatalhöyük East, Turkey’ Antiquity 89: 154- 76. https://doi.org/10.15184/aqy.2014.33 
Marciniak, A., Dembowiak, M., Hordecki, J., Stosik, W., Mickiewicz, A. 2016: 'Excavations in the TPC Area' in Çatal- höyük 2016 Archive Report. http://www.catalhoyuk.com/archive_reports/2015

Martinoli, D., Jacomet, S. 2004: 'Identifying endocarp remains and exploring their use at Epipalaeolithic Öküzini in southwest Anatolia, Turkey' Vegetation History and Archaeobotany 13: 45-54. https://doi.org/10.1007/s00334-003-0029-0

Mellaart, J. 1962: 'Excavations at Çatal Hüyük: first preliminary report' Anatolian Studies 12: 41-65. https://doi.org/10.2307/3642517

1964: 'Excavations at Çatal Hüyük, 1963' Anatolian Studies 14: 39-119. https://doi.org/10.2307/3642466 Middleton, C. 2014: The Nature of the Earliest Animal Management in Central Anatolia 13,000-5,000 cal BC: A Stable

Isotope Study. $\mathrm{PhD}$ thesis, University of Liverpool

Neef, R. 2003: 'Overlooking the steppe forest: preliminary report on the botanical remains from early Neolithic Göbekli Tepe (southern Turkey)’ Neolithics 2:13-15

Nesbitt, M. 2002: 'Where and when did domesticated cereals first occur in southwest Asia?' in R.T.J. Cappers, S. Bottema (eds), The Dawn of Farming in the Near East. Berlin, ex oriente: 113-32

Nesbitt, R., Peasnall, B.I., Redding, R.W., Rosenberg, M. 1998: 'Hallan Çemi, pig husbandry, and post-Pleistocene adaptations along the Taurus-Zagros Arc (Turkey)' Paléorient 24: 25-41. https://doi.org/10.3406/paleo.1998.4667

Orton, D., Rogasch, J., Gibson, C., Last, J., Bogaard, A., Rosenstock, E., Biehl, P. in preparation: 'A tale of two tells: dating the Çatalhöyük West Mound'

Özbaşaran, M. 2012: 'Aşıkl1' in M. Özdoğan, N. Başgelen, P. Kuniholm (eds), The Neolithic in Turkey 3. Central Turkey. Istanbul, Arkeoloji ve Sanat Yayınları: 135-58

Özbaşaran, M., Buitenhuis, H. 2002: 'Proposal for a regional terminology for central Anatolia' in F. Gérard, L. Thissen (eds), The Neolithic of Central Anatolia. Internal Developments and External Relations During the 9th-6th Millennia Cal BC. Proceedings of the International CANeW Table Ronde Istanbul, 23-24 November 2001. Istanbul: Ege Yayınları: 67-77 Özbaşaran, M., Duru, G. 2013: 'Istanbul (IST) Area of the East Mound' in I. Hodder (ed.), Excavating Çatalhöyük: The 2000-2008 Seasons. Los Angeles/London, Cotsen Institute of Archaeology/British Institute at Ankara: 621-58

Palmer, S.A., Moore, J.D., Clapham, A.J., Rose, P., Allaby, R.G. 2009: 'Archaeogenetic evidence of ancient Nubian barley evolution from six- to two-row indicates local adaptation' PLOS ONE 4.7: e6301. https://doi.org/10.1371/journal.pone.0006301

Pasternak, R. 1998: 'Investigation of botanical remains from Nevalı Çori, PPNB, Turkey: a short interim report' in A.B. Damania, J. Valkoun, G. Willcox, C.O. Qualset (eds), The Origins of Agriculture and Crop Domestication. Aleppo, ICARDA: 170-77

Peters, J., Buitenhuis, H., Grupe, G., Schmidt, K., Pöllath, N. 2013: 'The long and winding road: ungulate exploitation and domestication in early Neolithic Anatolia (10000-7000 cal BC)' in S. Colledge, J. Conolly, K. Dobney,

K. Manning, S. Shennan (eds), The Origins and Spread of Domestic Animals in Southwest Asia and Europe. Walnut Creek, Left Coast Press: 83-114

Peters, J., von den Driesch, A., Helmer, D. 2005: 'The upper Euphrates-Tigris basin: cradle of agropastoralism?' in J.-D. Vigne, J. Peters, D. Helmer (eds), The First Steps of Animal Domestication. Oxford, Oxbow: 96-124

Pitter, S., Yalman, N., Evershed, R. 2013: 'Absorbed lipid residues in the Çatalhöyük pottery’ in I. Hodder (ed.), Substan- tive Technologies at Çatalhöyük: Reports from the 2000-2008 Seasons. Los Angeles/London, Cotsen Institute of Archaeology/British Institute at Ankara: 193-200

Regan, R., Taylor, J. 2014: 'The sequence of Buildings 75, 65, 6, 69, 44 and 10 and External Spaces $119,129,130,144$,

299, 314, 319, 329, 333, 339, 367, 371 and 427' in I. Hodder (ed.), Çatalhöyük Excavations: The 2000- 
2008 Seasons. Los Angeles/London, Cotsen Institute of Archaeology/British Institute at Ankara: 13190

Riehl, S. 2009: 'Archaeobotanical evidence for the interrelationship of agricultural decision-making and climate change in the ancient Near East' Quaternary International 197: 93-114. https://doi.org/10.1016/j.quaint.2007.08.005

Riehl, S., Benz, M., Conard, N.J., Darabi, H., Deckers, K., Fazeli Nashli, H., Zeidi-Kulehparcheh, M. 2012: 'Plant use in three Pre-Pottery Neolithic sites of the northern and eastern Fertile Crescent: a preliminary report' Vegetation History and Archaeobotany 21: 95-106. https://doi.org/10.1007/s00334-011-0318-y

Roberts, N., Allcock, S.L., Arnaud, F., Dean, J.R., Eastwood, W.J., Jones, M.D., Leng, M.L., Metcalfe, S.E., Malet, E., Woodbridge, J., Yiğitbaşığlu, H. 2016: 'A tale of two lakes: a multi-proxy comparison of Late Glacial and Holocene environmental change in Cappadocia, Turkey' Journal of Quaternary Science 31: 348-61. https://doi.org/10.1002/jqs.2852

Roberts, N., Rosen, A. 2009: 'Diversity and complexity in early farming communities of southwest Asia: new insights into the economic and environmental basis of Neolithic Çatalhöyük' Current Anthropology 50: 393-402. https://doi.org/10.1086/598606

Russell, N., Twiss, K.C., Orton, D.C., Demirergi, G.A. 2013: 'More on the Çatalhöyük mammal remains' in I. Hodder (ed.), Humans and Landscapes of Çatalhöyük: Reports from the 2000-2008 Seasons. Los Angeles/London, Cotsen Institute of Archaeology/British Institute at Ankara: 213-58

Savard, M. 2005: Epipalaeolithic to Early Neolithic Subsistence Strategies in the Northern Fertile Crescent: The Archaeo- botanical Remains from Hallan Çemi, Demirköy, M'lefaat and Qermez Dere. $\mathrm{PhD}$ thesis, University of Cambridge

Stiner, M.C., Buitenhuis, H., Duru, G., Kuhn, S.L., Mentzer, S.M., Munro, N.D., Pöllath, N., Quade, J., Tsartsidou, G., Özbaşaran, M. 2014: 'A forager-herder trade-off, from broad-spectrum hunting to sheep management at Aşıklı Höyük, Turkey’ Proceedings of the National Academy of Sciences 111: 840409. https://doi.org/10.1073/pnas.1322723111

Stroud, E., Bogaard, A. in preparation: 'A stable isotopic investigation into Chalcolithic cultivation practices at Çatal- höyük and Camlibel Tarlası, central Anatolia'

Stroud, E., Bogaard, A., Charles, M. in preparation: 'A comparative archaeobotanical perspective on Chalcolithic farming in central Anatolia: Çatalhöyük and Camlibel Tarlası'

Valamoti, S.M. 2009: "Plant food ingredients and "recipes" from prehistoric Greece: the archaeobotanical evidence' in

J.P. Morel, A.M. Mercuri (eds), Plants and Culture: Seeds of the Cultural Heritage of Europe. Bari, Edipuglia

van Zeist, W., de Roller, G.J. 1995: 'Plant remains from Aşılılı Höyük: a Pre-Pottery Neolithic site in central Anatolia'

Vegetation History and Archaeobotany 4: 179-85. https://doi.org/10.1007/BF00203936

- 2003a: 'Some notes on the plant husbandry of Aş1klı Höyük' in W. van Zeist (ed.), Reports on Archaeobotanical Studies in the Old World. Groningen: 115-42

- 2003b: 'The Çayönü archaeobotanical record' in W. van Zeist (ed.), Reports on Archaeobotanical Studies in the Old World. Groningen: 143-66

Voltas, J., Romagosa, I., Lafarga, A., Sombrero, A. 1999: 'Genotype by environment interaction for grain yield and carbon isotope discrimination of barley in Mediterranean Spain' Australian Journal of Agricultural Research 50: 1263-71. https://doi.org/10.1071/AR98137

Wallace, M.P., Jones, G., Charles, M., Fraser, R., Heaton, T.H.E., Bogaard, A. 2015: 'Stable carbon isotope evidence for Neolithic and Bronze Age crop water management in the eastern Mediterranean and southwest Asia' PLOS ONE 10.6: e0127085. https://doi.org/10.1371/journal.pone.0127085

Willcox, G. 2013: 'The roots of cultivation in southwestern Asia' Science 341: 39-40. 
https://doi.org/10.1126/science.1240496

Yalman, N., Tarkan, D., Gültekin, H. 2013: 'The Neolithic pottery of Çatalhöyük: recent studies' in Hodder (ed.), Substantive Technologies at Çatalhöyük: Reports from the 2000-2008 Seasons. Los Angeles/London, Cotsen Institute of Archaeology/British Institute at Ankara: 147-82 
Figures for "Agricultural innovation and resilience in a long-lived early farming community..."

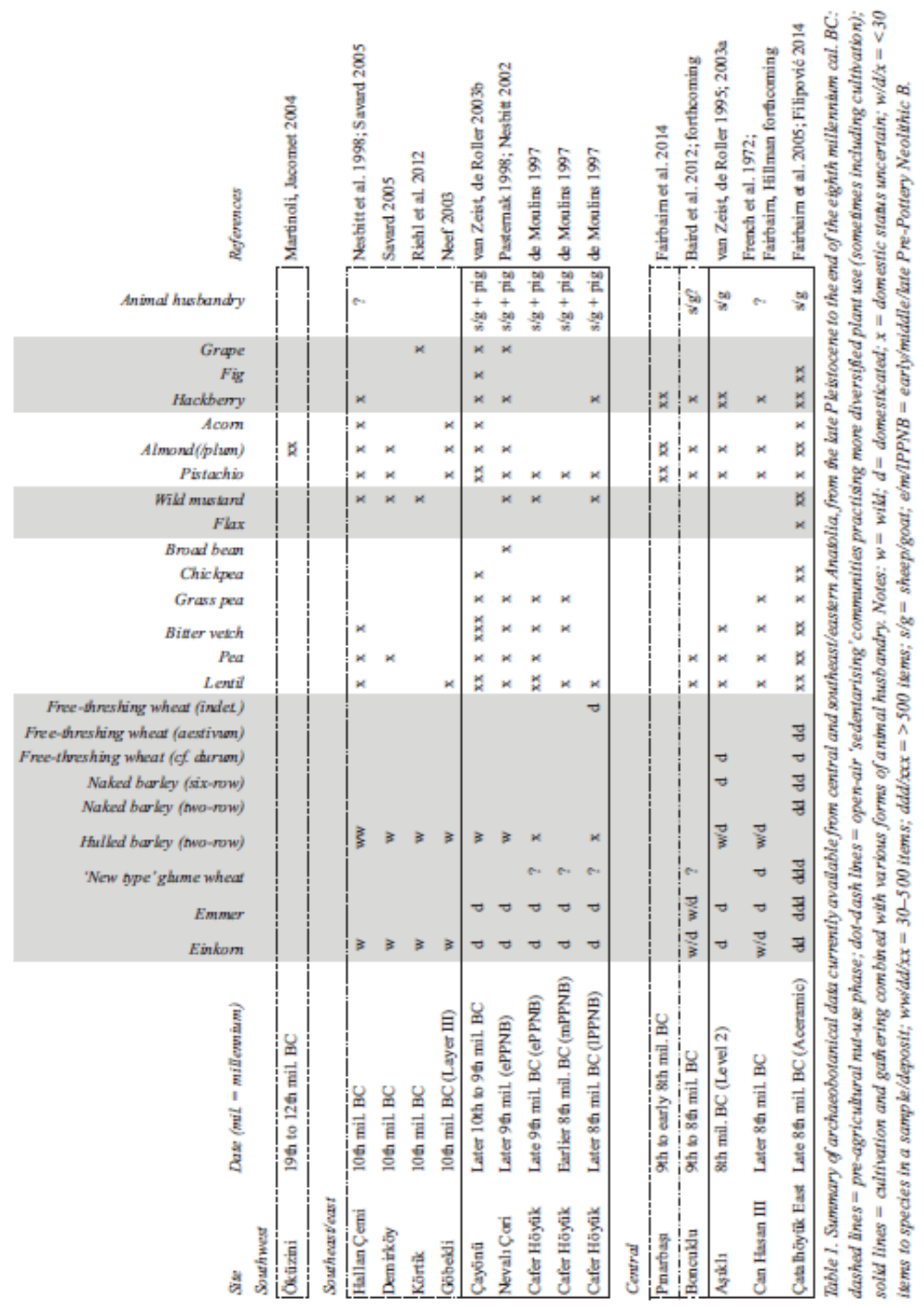



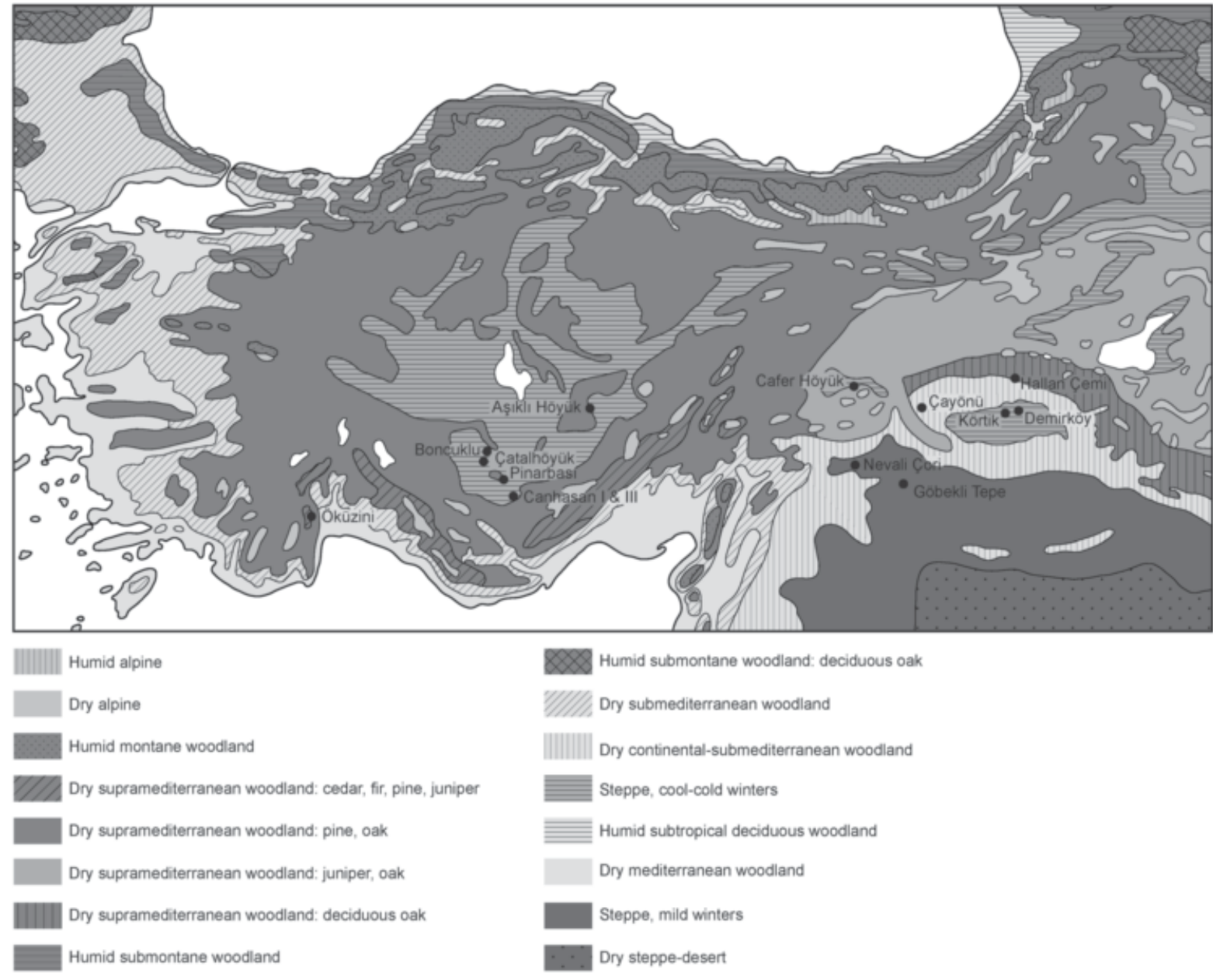

Fig. 1. Map showing the location of Çatalhöyük and other Anatolian sites mentioned in the text (vegetation zones follow Hütteroth, Höhfeld 2002: fig.44). 


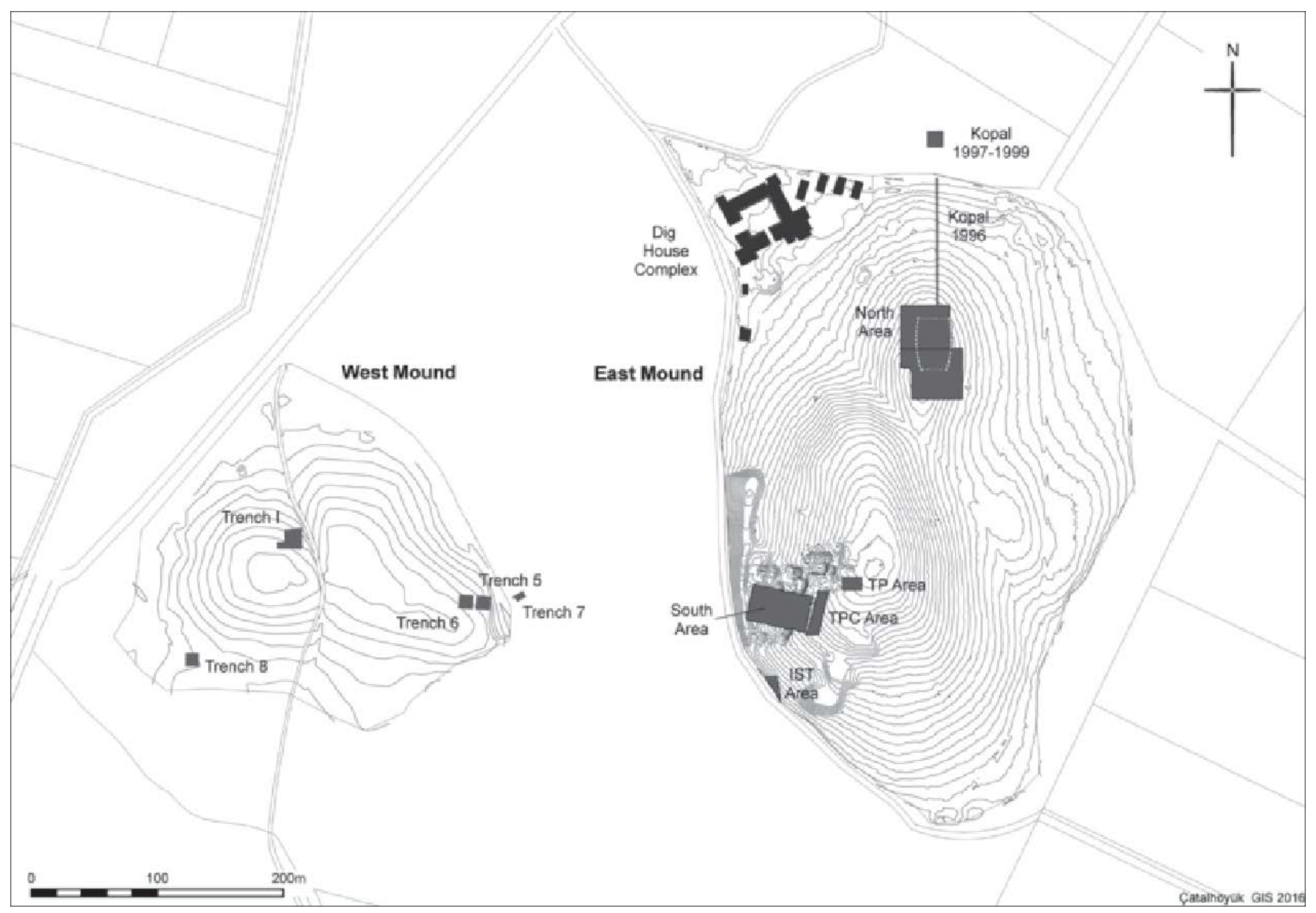

Fig. 2. Plan of Çatalhöyük showing the East and West Mounds and major excavation areas mentioned in the text.

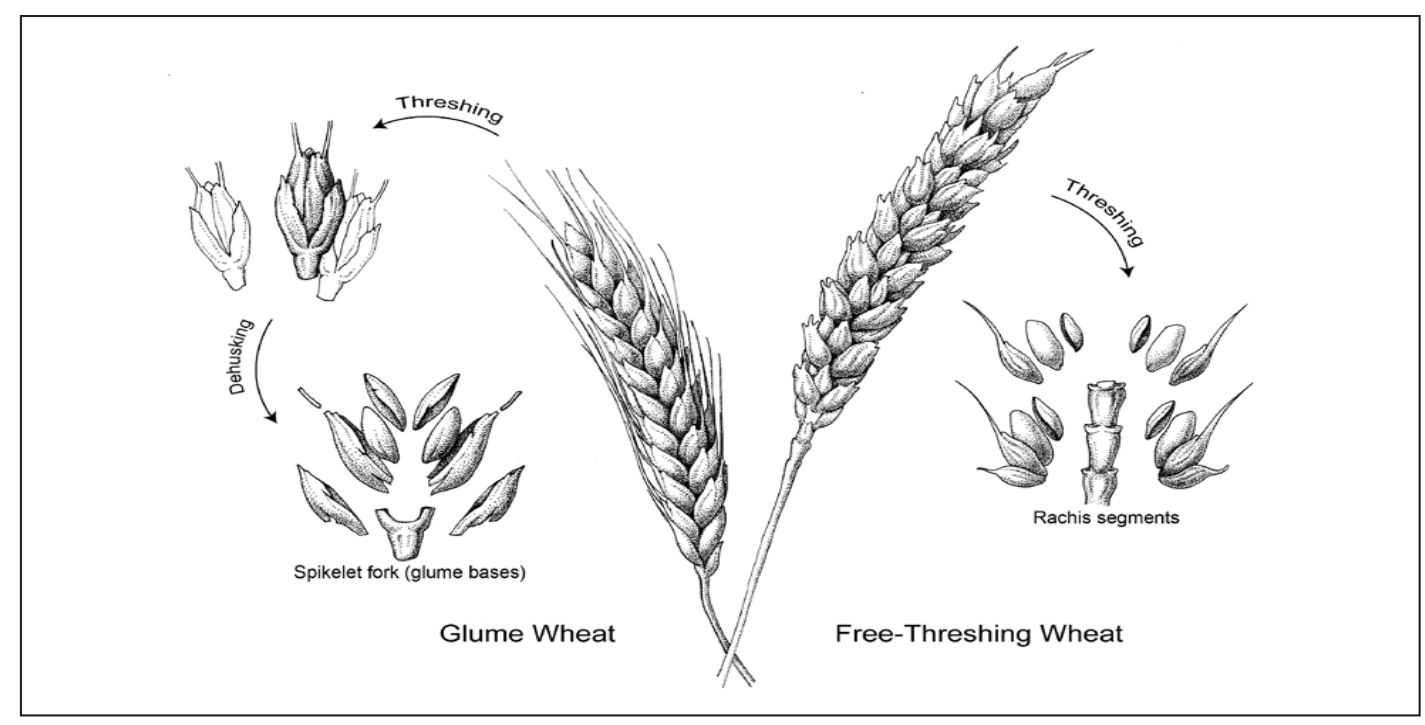

Fig. 3. Schematic representation of the structure and processing stages of glume (or hulled) and free-threshing wheat; barleys (whether naked or hulled) behave under processing like free-threshing wheat and are thus represented as grains and rachis segments. 


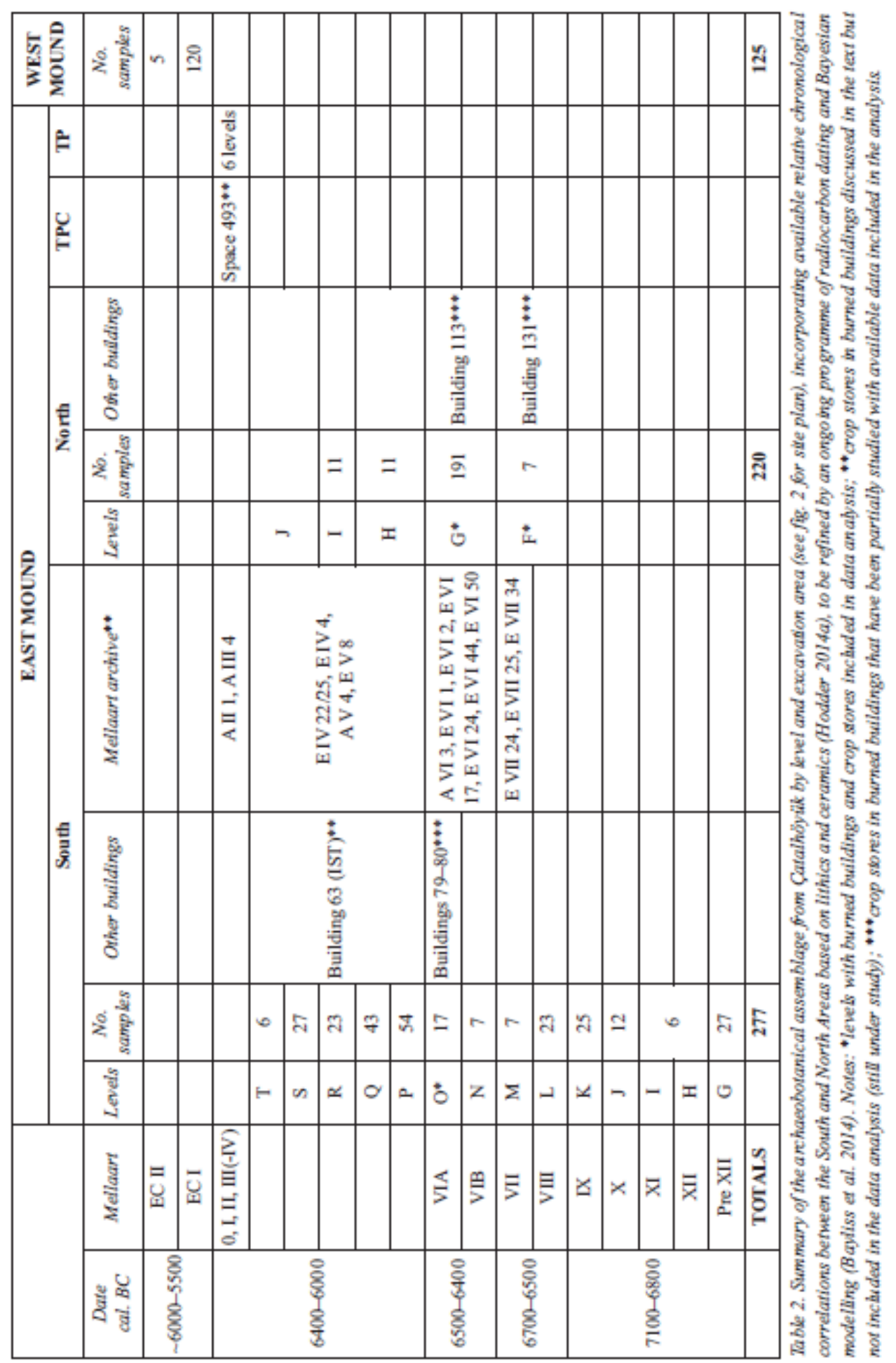




\begin{tabular}{|c|c|c|c|c|c|c|c|c|c|}
\hline & $\begin{array}{l}\stackrel{0}{E} \\
\frac{5}{5} \\
0\end{array}$ & $\begin{array}{l}z \\
\pm \\
\bar{E} \\
8 \\
8\end{array}$ & $\frac{z}{5}$ & $\begin{array}{l}\underline{y} \\
\frac{\mathbf{E}}{5} \\
0\end{array}$ & $\frac{\vec{Z}}{5}$ & $\frac{\Sigma}{\mathbf{E}}$ & $\frac{z}{\mathbf{z}}$ & 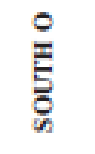 & $\frac{}{5}$ \\
\hline \multirow[t]{2}{*}{ Total samples } & 27 & 6 & 12 & 25 & 23 & 7 & 7 & 21 & 54 \\
\hline & \multicolumn{9}{|c|}{ Presence in samples } \\
\hline \multicolumn{10}{|l|}{ Genend categories } \\
\hline CEREAL & 27 & 6 & 12 & 25 & 23 & 7 & 7 & 19 & 39 \\
\hline PULSE & 27 & 6 & 12 & 22 & 22 & 7 & 4 & 4 & 33 \\
\hline FRUTT/NUT & 27 & 6 & 11 & 24 & 21 & 7 & 2 & 3 & 36 \\
\hline \multirow[t]{2}{*}{ MUSTARD } & 12 & 2 & & 3 & 3 & 1 & 1 & 9 & 26 \\
\hline & \multicolumn{9}{|c|}{ Counts of hotanical items } \\
\hline CEREAL GRAIN & 6,763 & 237 & 331 & 836 & 3,926 & 424 & 65 & 13,408 & 3,196 \\
\hline CEREAL CHAFF & 14,981 & 1,728 & 3,380 & 5,866 & 22,045 & 5,434 & 576 & 1,099 & 4,384 \\
\hline PULSE & 4,093 & 72 & 142 & 240 & 543 & 119 & 8 & 618 & 116 \\
\hline FRUTT/NUT & 1,740 & 50 & 112 & 172 & 348 & 51 & 15 & 4 & 531 \\
\hline MUSTARD & 2,567 & 2 & & 3 & 60 & 2 & 16 & 176 & 337 \\
\hline \multicolumn{10}{|l|}{ Ceneal gruin** } \\
\hline GLUME WHE.AT GRAIN & 1,193 & 11 & 36 & 94 & 481 & 63 & 4 & 1,411 & 193 \\
\hline FREE-THRESHING WHEAT GR AIN & 681 & 1 & & 8 & 52 & 5 & 2 & 5,448 & 60 \\
\hline NAKED BARLEY GRAIN & 273 & 19 & 11 & 19 & 33 & 12 & 4 & 5,455 & 117 \\
\hline \multicolumn{10}{|l|}{ HULLED BARLEY GRAIN } \\
\hline \multicolumn{10}{|l|}{ Ceneal chaff } \\
\hline WILD EINKORN GLUME BASE & & & & 16 & 2 & 4 & & & \\
\hline EINKORN GLUME BASE & 344 & 21 & 65 & 132 & 496 & 194 & 5 & 1 & 107 \\
\hline EMMER GLUME BASE & 4,177 & 409 & 640 & 1,285 & 9,970 & 1,952 & 205 & 153 & 85 \\
\hline 'NEW TYPE' WHEAT GLUME BASE & 89 & 24 & 58 & 244 & 567 & 154 & 33 & 15 & 195 \\
\hline FREE-THRESHING WHEAT RACHIS & 590 & 59 & 86 & 185 & 606 & 86 & 12 & 497 & 145 \\
\hline BARLEY RACHIS & 26 & 28 & 20 & 57 & 99 & 23 & 10 & 61 & 90 \\
\hline \multicolumn{10}{|l|}{ Barley rachis* } \\
\hline NAKED SIX-ROW RACHIS & 22 & 19 & 8 & 11 & 53 & & 1 & & 1 \\
\hline NAKED TWO-ROW RACHIS & 1 & & 3 & 16 & 28 & 22 & 4 & 28 & 75 \\
\hline \multicolumn{10}{|l|}{ CF. HULLED TWO-ROW RACHIS } \\
\hline \multicolumn{10}{|l|}{ Pulsest } \\
\hline LENTIL & 1,736 & 4 & 30 & 102 & 192 & 39 & 6 & & 5 \\
\hline PEA & 155 & 2 & 15 & 12 & 21 & 11 & 1 & 618 & 24 \\
\hline BITTER VETCH & 753 & 18 & 33 & 26 & 78 & 12 & & & 11 \\
\hline CHICKPEA & 128 & & & 3 & 1 & & & & 6 \\
\hline GRASS PEA & 83 & & & & 2 & & & & \\
\hline \multicolumn{10}{|l|}{ Frued'nut smox } \\
\hline ALMOND & 1 & & & & & & & & 4 \\
\hline ALMOND/PLUM & 115 & 14 & 11 & 13 & 19 & 4 & 9 & 1 & 29 \\
\hline PISTACHIO & 80 & 8 & 16 & 8 & 11 & 3 & 1 & & 30 \\
\hline HACKBERRY & 1,393 & 24 & 71 & 137 & 278 & 30 & 5 & 2 & 408 \\
\hline ACORN & 34 & 4 & 13 & 14 & 11 & 4 & & 1 & 4 \\
\hline OTHER (including fig) & 117 & & 1 & & 29 & 10 & & & 56 \\
\hline
\end{tabular}

Table 3. Summary of the occurrence of crops and gathered plants by excavation area and level. Note: "excluding indeterminate categories. 


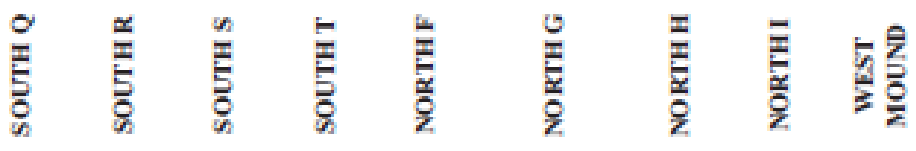

Total samples

$\begin{array}{lll}43 & 23 & 27\end{array}$

192

125

General categories

CEREAL

PULSE

FRUIT/NUT

MUSTARD

CEREAL GRAIN

Presence in samples

$\begin{array}{lllllllll}39 & 23 & 26 & 6 & 10 & 173 & 10 & 11 & 125 \\ 26 & 16 & 14 & 6 & 8 & 115 & 8 & 11 & 104 \\ 32 & 16 & 18 & 6 & 5 & 126 & 8 & 11 & 117 \\ 17 & 11 & 6 & 4 & 1 & 107 & 4 & 2 & 99\end{array}$

\section{Counts of botanical items}

CEREAL CHAFF

$\begin{array}{ccccccccc}936 & 474 & 552 & 195 & 141,182 & 43,782 & 419 & 1,242 & 4,424 \\ 4,585 & 1,361 & 1,167 & 1,121 & 105,294 & 52,799 & 3,242 & 1,407 & 77,781 \\ 139 & 100 & 62 & 22 & 260 & 70,784 & 54 & 56 & 550 \\ 322 & 205 & 137 & 215 & 28 & 1,147 & 588 & 133 & 1,148 \\ 702 & 4,142 & 45 & 64 & 4 & 127,332,461 & 74 & 33 & 4,293\end{array}$

FRUIT/NUT

MUSTARD

$\begin{array}{lllllllll}702 & 4,142 & 45 & 64 & 4 & 127,332,461 & 74 & 33 & 4,293\end{array}$

Cereal grain*

$\begin{array}{ccccccccc}30 & 12 & 10 & 8 & 140,460 & 1225 & 40 & 95 & 609 \\ 30 & 25 & 12 & 10 & 12 & 10,927 & 15 & 112 & 224 \\ 50 & 29 & 5 & 6 & 6 & 15,171 & 14 & 118 & 43 \\ 3 & & & 3 & & 5 & 1 & 5 & 295\end{array}$

\section{NAKED BARLEY GRAIN}

HULLED BARLEY GRAIN

Ceneal chaff

WILD EINKORN GLUME BASE

EINKORN GLUME BASE

EMMER GLUME BASE

'NEW TYPE' WHEAT GLUMEBASE

FREE-THRESHING WHEAT RACHIS
BARLEY RACHIS

\begin{tabular}{|c|c|c|c|c|c|c|c|}
\hline 5 & & & 20 & 39 & & & 4 \\
\hline 2 & & 1 & 125 & 333 & 9 & 11 & 271 \\
\hline 4 & 8 & 15 & 2,434 & 5,604 & 31 & 71 & 2,155 \\
\hline 177 & 107 & 60 & 92,373 & 7,327 & 79 & 340 & 3,613 \\
\hline 33 & 4 & 40 & 536 & 1,552 & 23 & 131 & 637 \\
\hline 34 & 5 & 8 & 77 & 739 & 18 & 25 & 905 \\
\hline
\end{tabular}

Barley rachis*

NAKED SIX-ROW RACHIS

NAKED TWO-ROW RACHIS

$230 \quad 15$

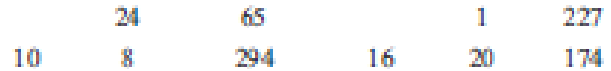

CF. HULLED TWO-ROW RACHIS

Pulves*

LENTIL

PEA

BITTER VETCH

CHICKPEA

GRASS PEA

$\begin{array}{ccccccccc}2 & 7 & 6 & 2 & 72 & 65,221 & 11 & 1 & 178 \\ 60 & 31 & 12 & 9 & 101 & 5,237 & 6 & 22 & 79 \\ 5 & 10 & 1 & 1 & 8 & 48 & 4 & 9 & 20 \\ 1 & & 1 & & 2 & 21 & & & 2 \\ & & & & 1 & 7 & & & 1\end{array}$

Fruidnut taxa*

ALMOND

ALMOND/PLUM

PISTACHIO

HACKBERRY

ACORN

OTHER (including fig)

$\begin{array}{ccccccccc}14 & 2 & 1 & & & 432 & & 3 & \\ 122 & 5 & 22 & 2 & 5 & 138 & 6 & 6 & 152 \\ 30 & 10 & 13 & 1 & 1 & 176 & 10 & 21 & 96 \\ 141 & 159 & 96 & 68 & 19 & 335 & 571 & 93 & 888 \\ 1 & & 1 & & 3 & 64 & & 7 & 10 \\ 14 & 29 & 4 & 144 & & 2 & 1 & 3 & 2\end{array}$

Table 3 (continued). Summary of the accurrence of crops and gathered plants by excavation area and level. Note:

"excluding indeterminate categories. 


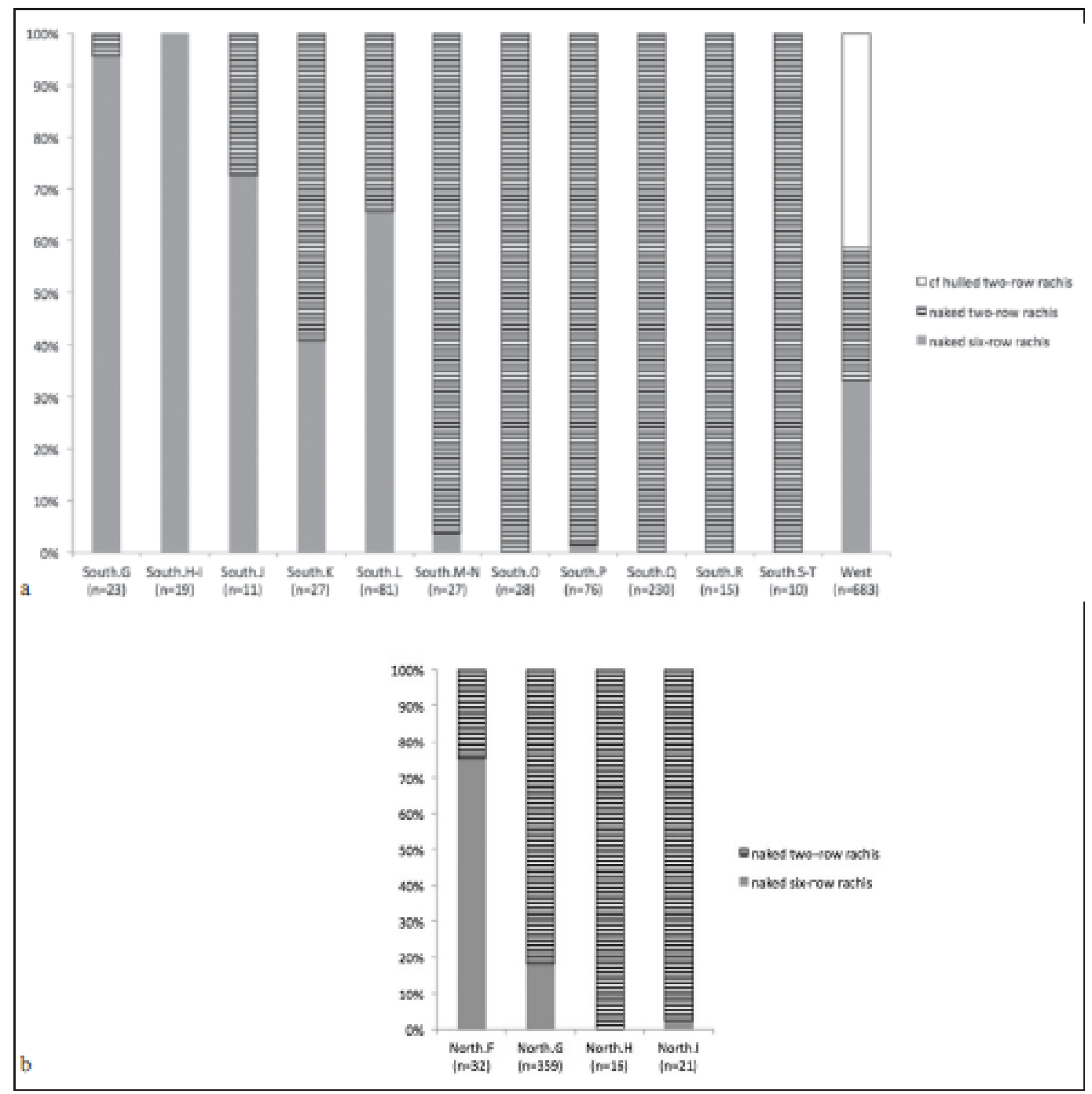

Fig. 4. Bar charts summarising proportions of barley rachis segments identified as two-row naked, six-row naked and (cf.) two-row hulled through time from (a) the South Area of the East Mound and the West Mound, and (b) the North Area of the East Mound. 


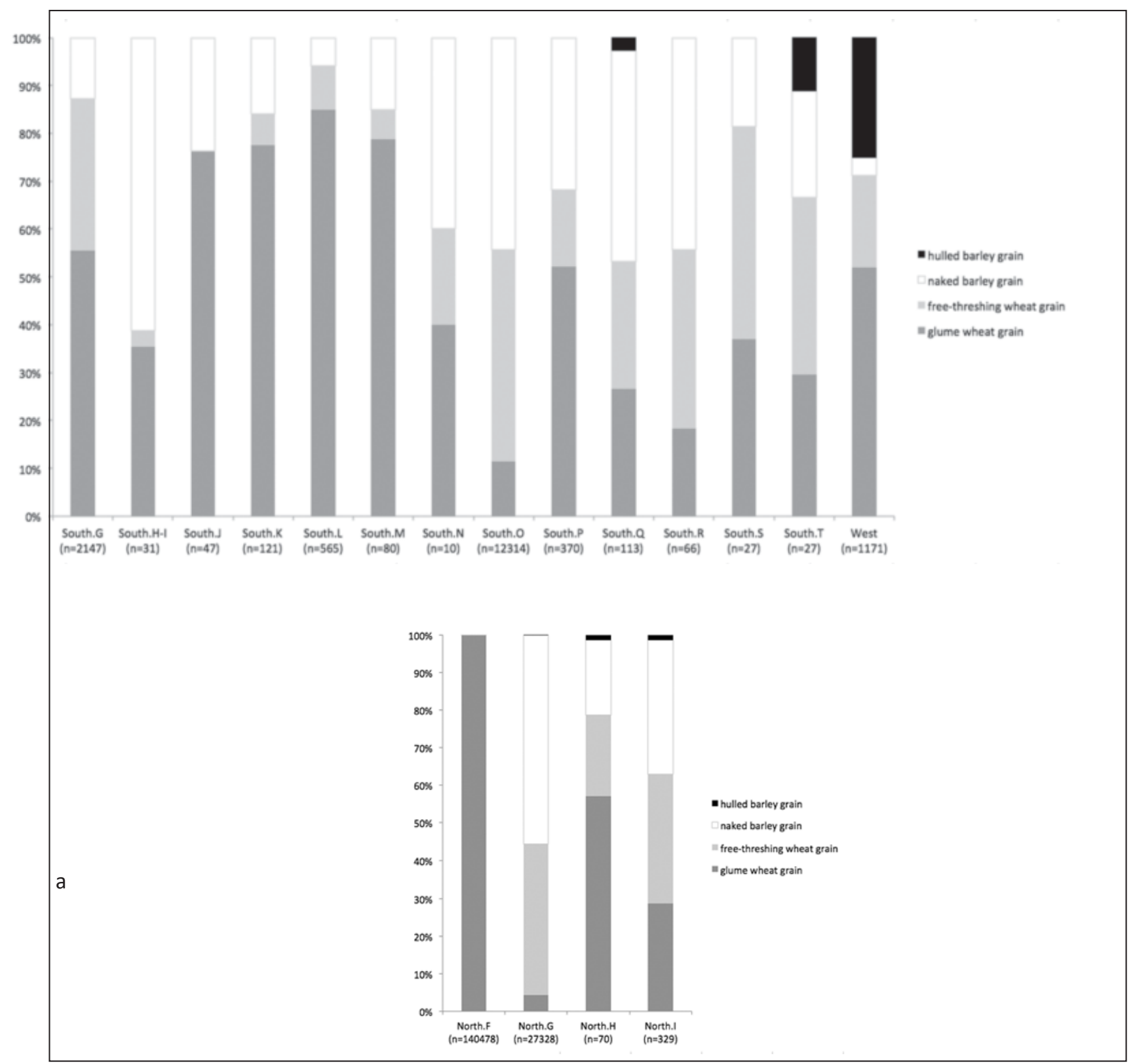

Fig. 5. Bar charts summarising proportions of cereal grain types through time from (a) the South Area of the East Mound and the West Mound, and (b) the North Area of the East Mound. 


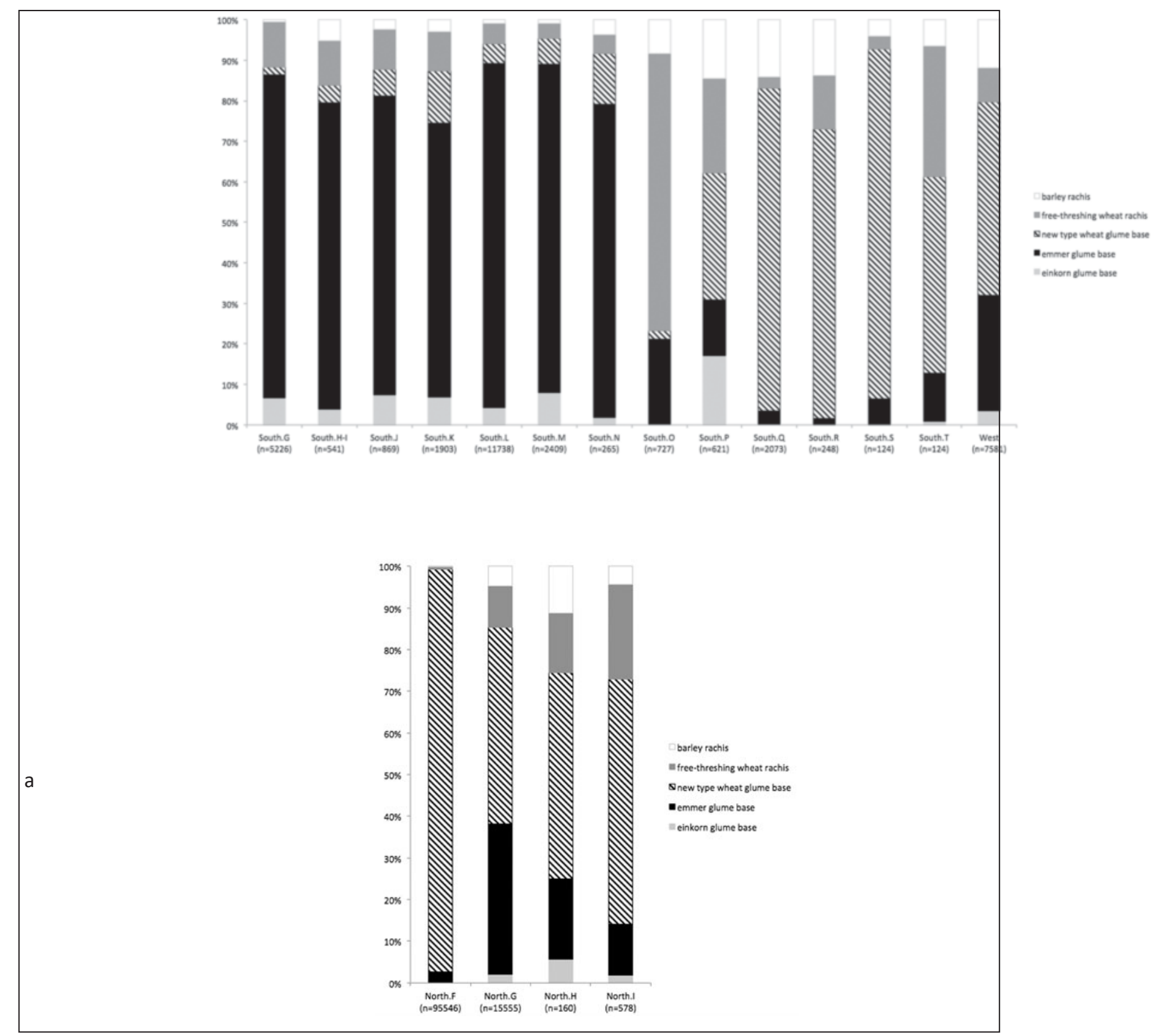

Fig. 6. Bar charts summarising proportions of cereal chaff remains through time from (a) the South Area of the East Mound and the West Mound, and (b) the North Area of the East Mound. 


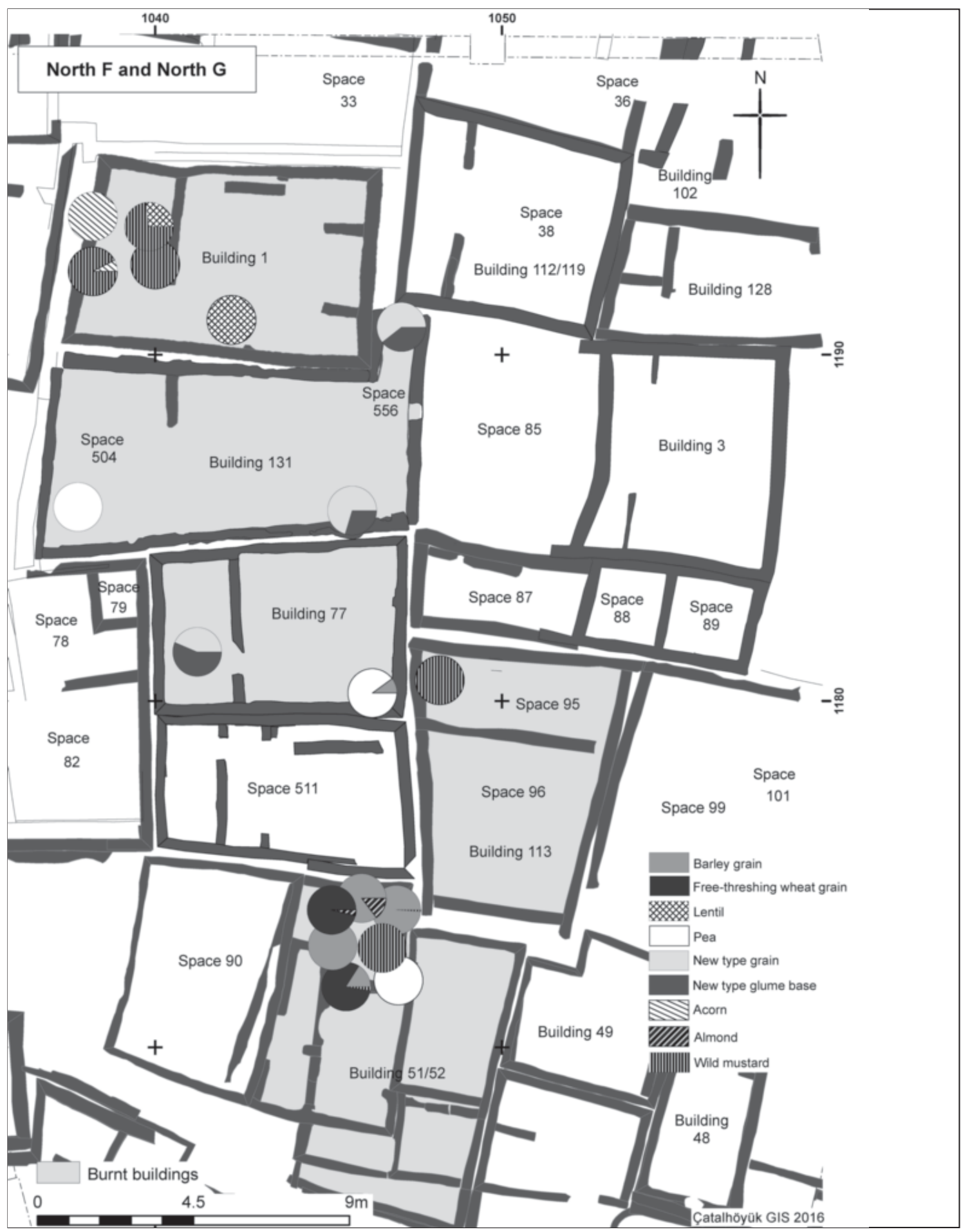

Fig. 7a. Plan of the North Area of the site, showing the composition of 'storage' concentrations of charred plant material preserved in burned buildings based on seed/chaff item counts. To provide a simplified overview of the major types of deposit in each structure, a single pie chart is shown where there are multiple similar adjacent concentrations, and minor components have been left out. Counts of the tiny seeds of wild mustard (for example Descurainia sophia) have been divided by 1,000 to improve the visibility of other components for this overview. Material from various buildings is still under study. 


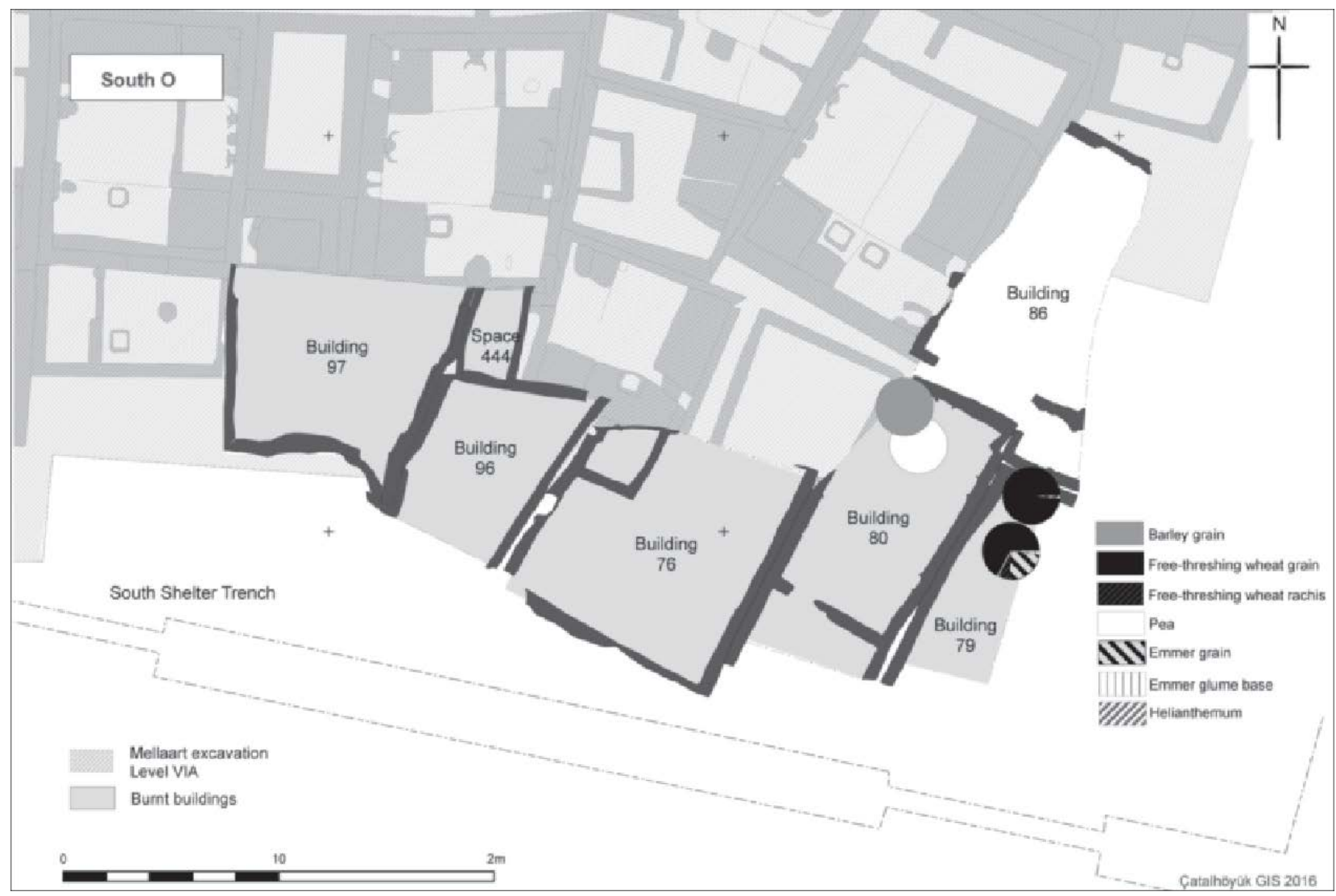

Fig. 7b. Plan of the South Area of the site, showing the composition of 'storage' concentrations of charred plant material preserved in burned buildings based on seed/chaff item counts. To provide a simplified overview of the major types of deposit in each structure, a single pie chart is shown where there are multiple similar adjacent concentrations, and minor components have been left out. Counts of rock rose (Helianthemum) have been divided by 1,000 to improve the visibility of other components for this overview. Material from various buildings is still understudy. 


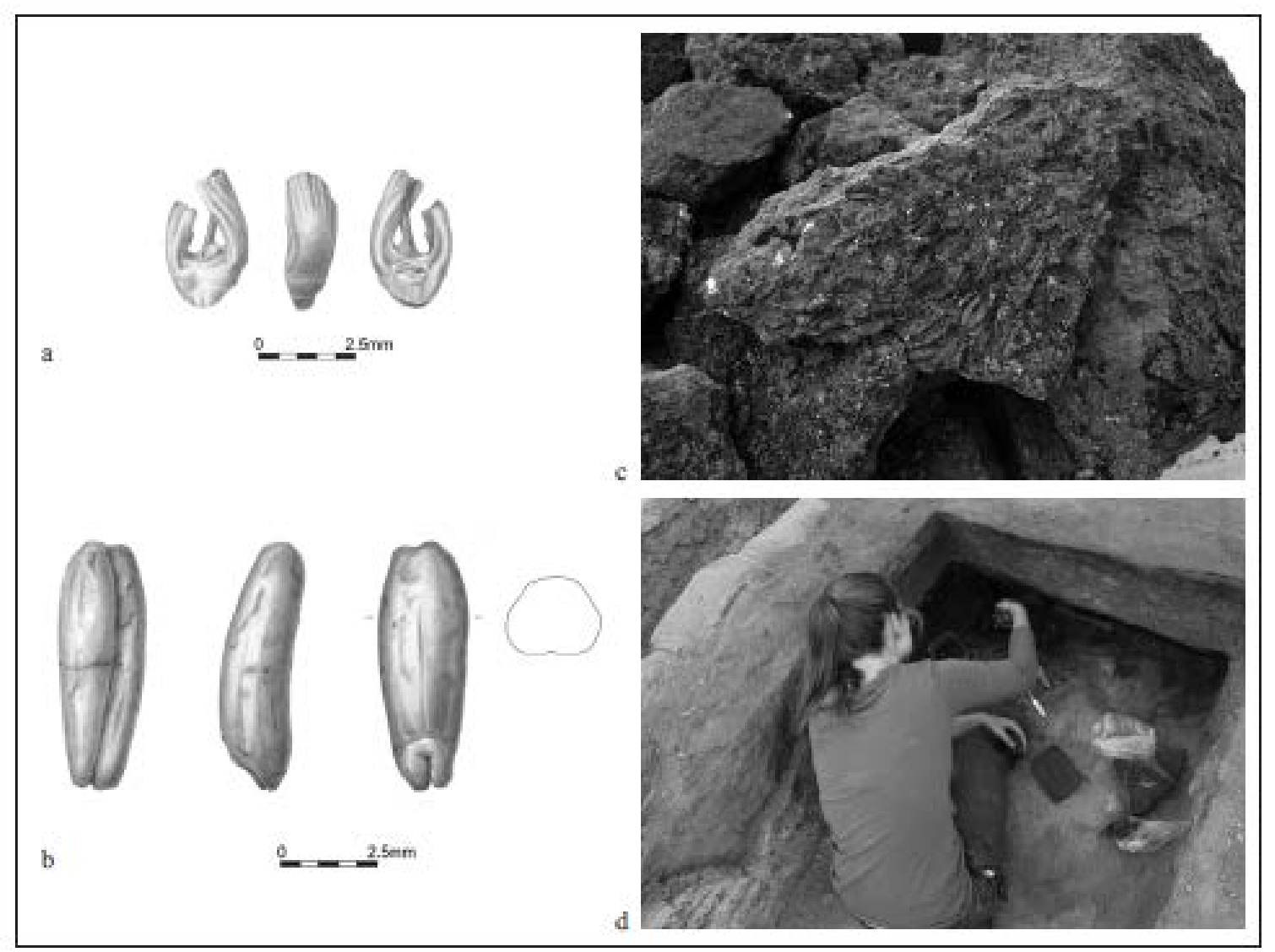

Fig. 8. 'New type' glume wheat: (a) spikelet fork; (b) grain (drawings by Katy Killackey); (c) intact spikelets in Building 77 (photo by Müge Ergun); (d) spikelet concentration in Building 131 under excavation in 2015 (photo by Jason Quinlan).

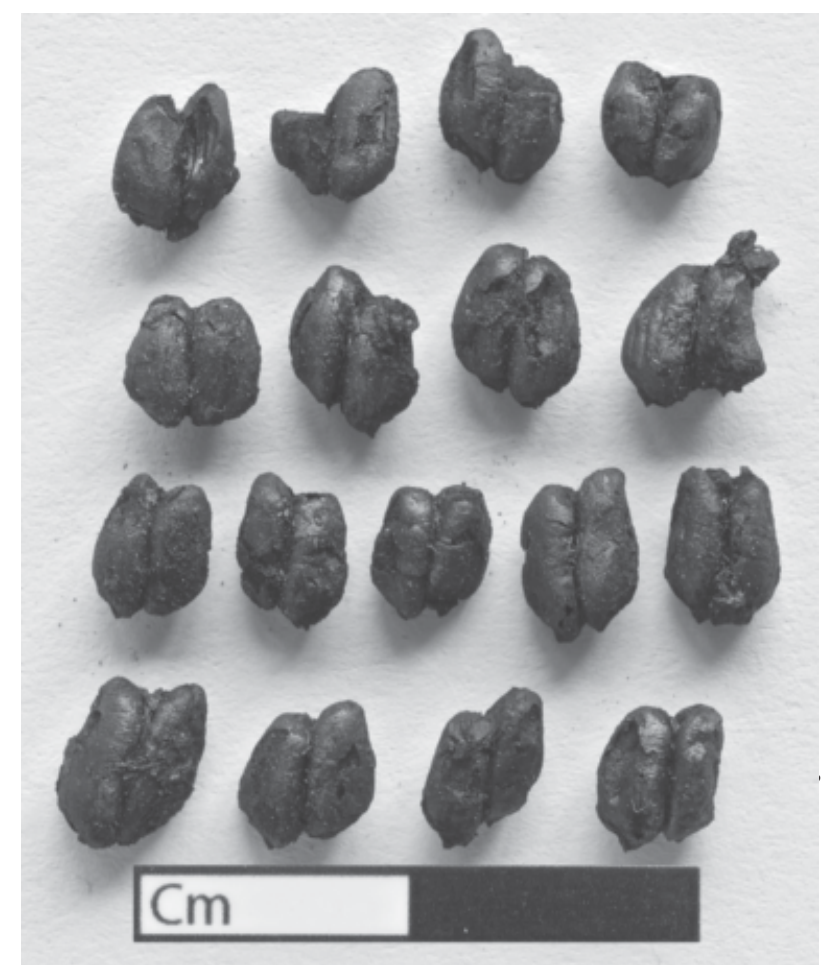

Intact pairs of emmer grains in stored ts, unit 18596 s.1, burned Building 79 O) (photo by Jason Quinlan). 


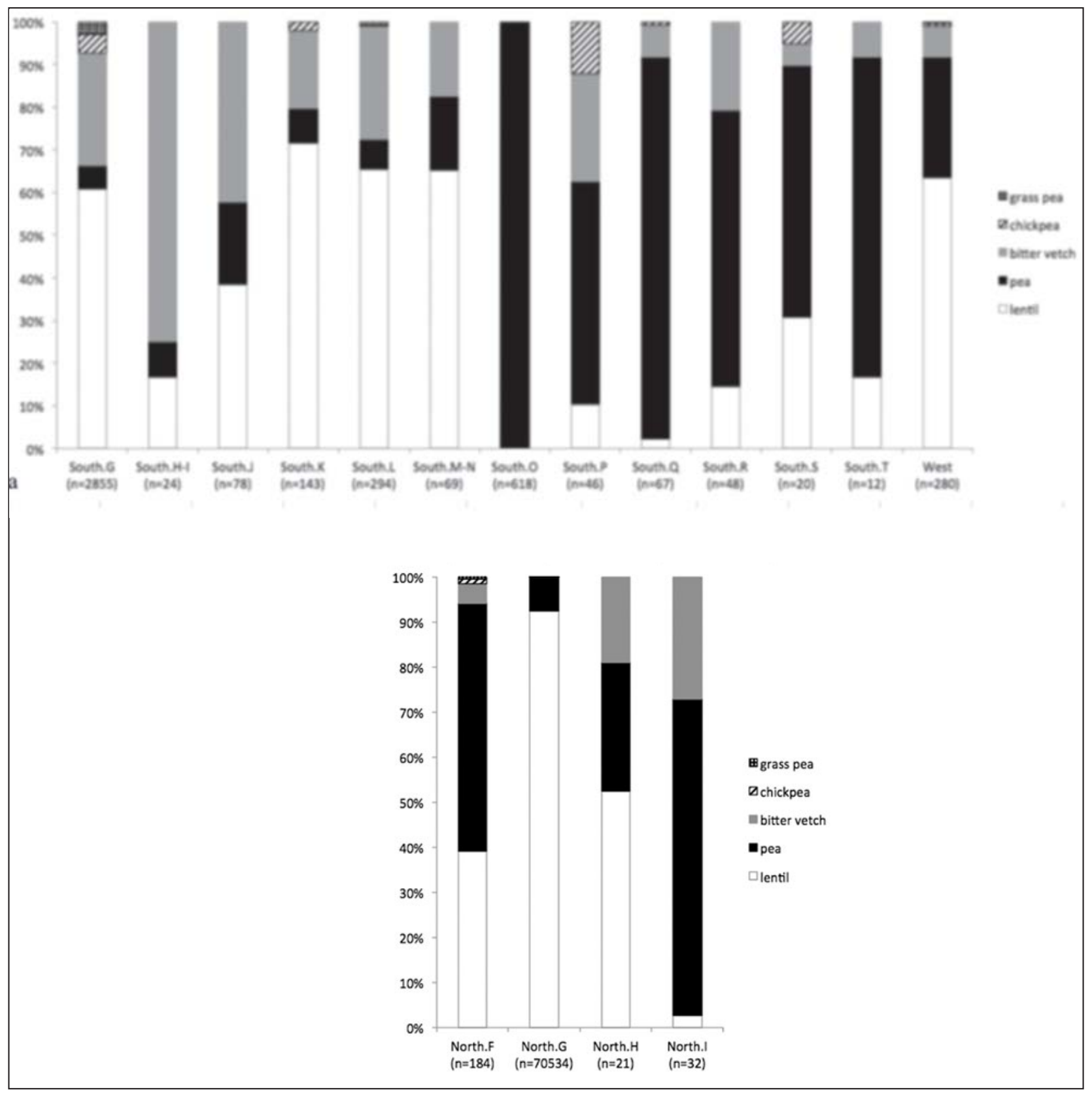

Fig. 10. Bar charts summarising proportions of pulse taxa through time from (a) the South Area of the East Mound and the West Mound, and (b) the North Area of the East Mound. 


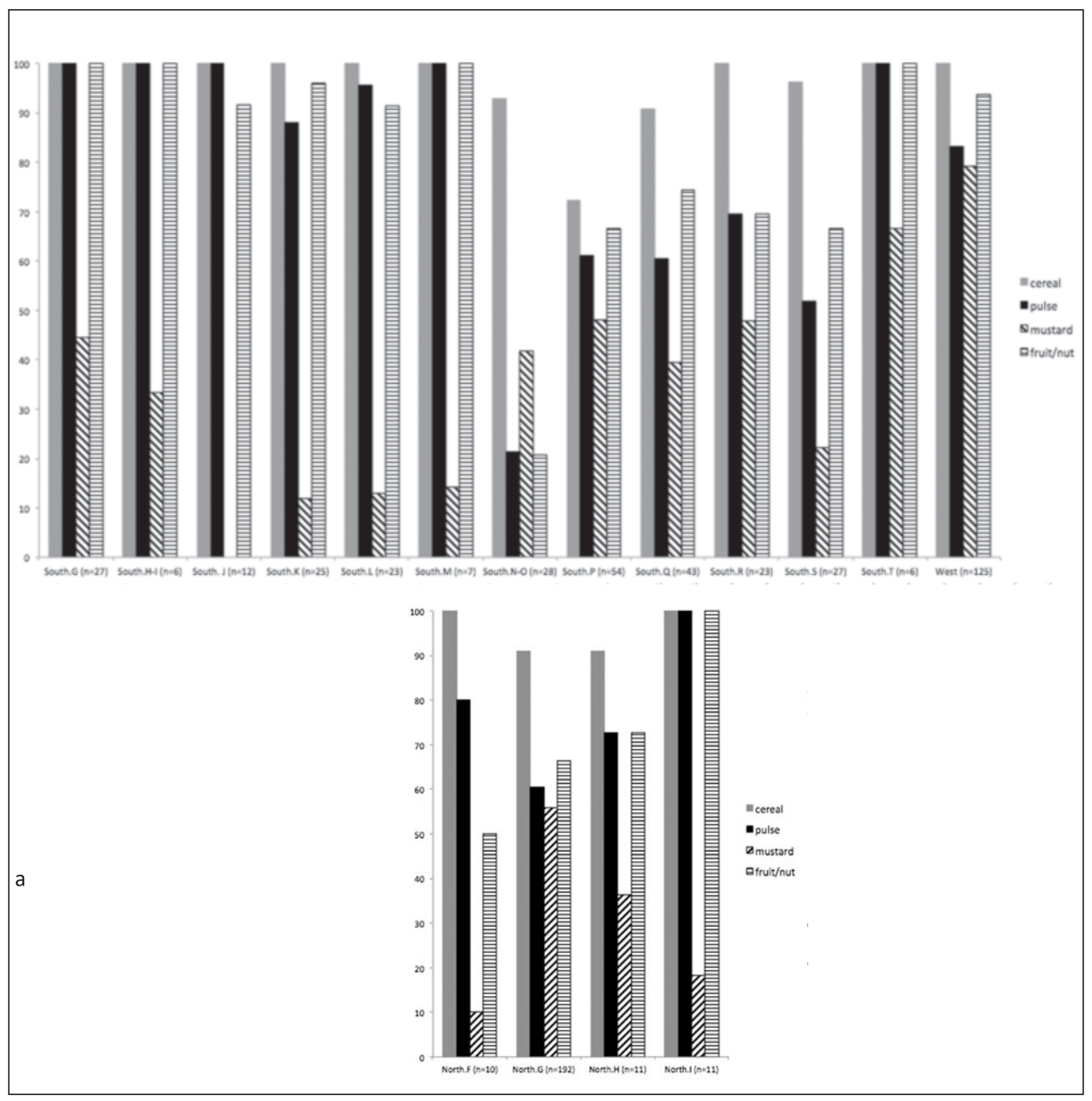

Fig. 11. Bar charts summarising ubiquities of cereal material, pulses, small-seeded mustard and fruit/nut taxa through time from (a) the South Area of the East Mound and the West Mound, and (b) the North Area of the East Mound. 


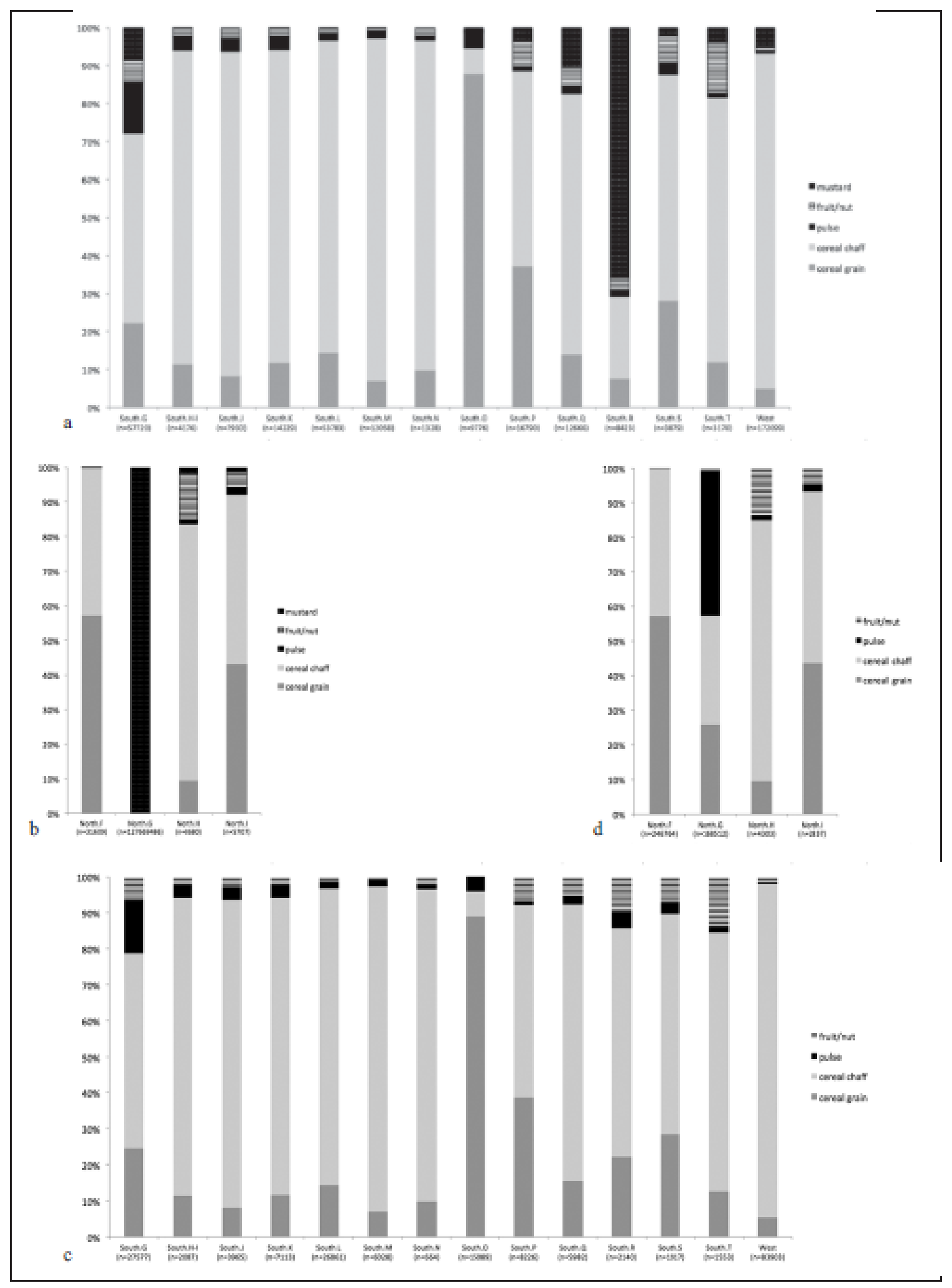

Fig. 12. Bar charts summarising proportions of cereal grain, cereal chaff, pulses, small-seeded mustard and fruit/nut taxa through time from (a) the South Area of the East Mound and the West Mound, and (b) the North Area of the East Mound; (c) and (d) show proportions excluding mustard. 


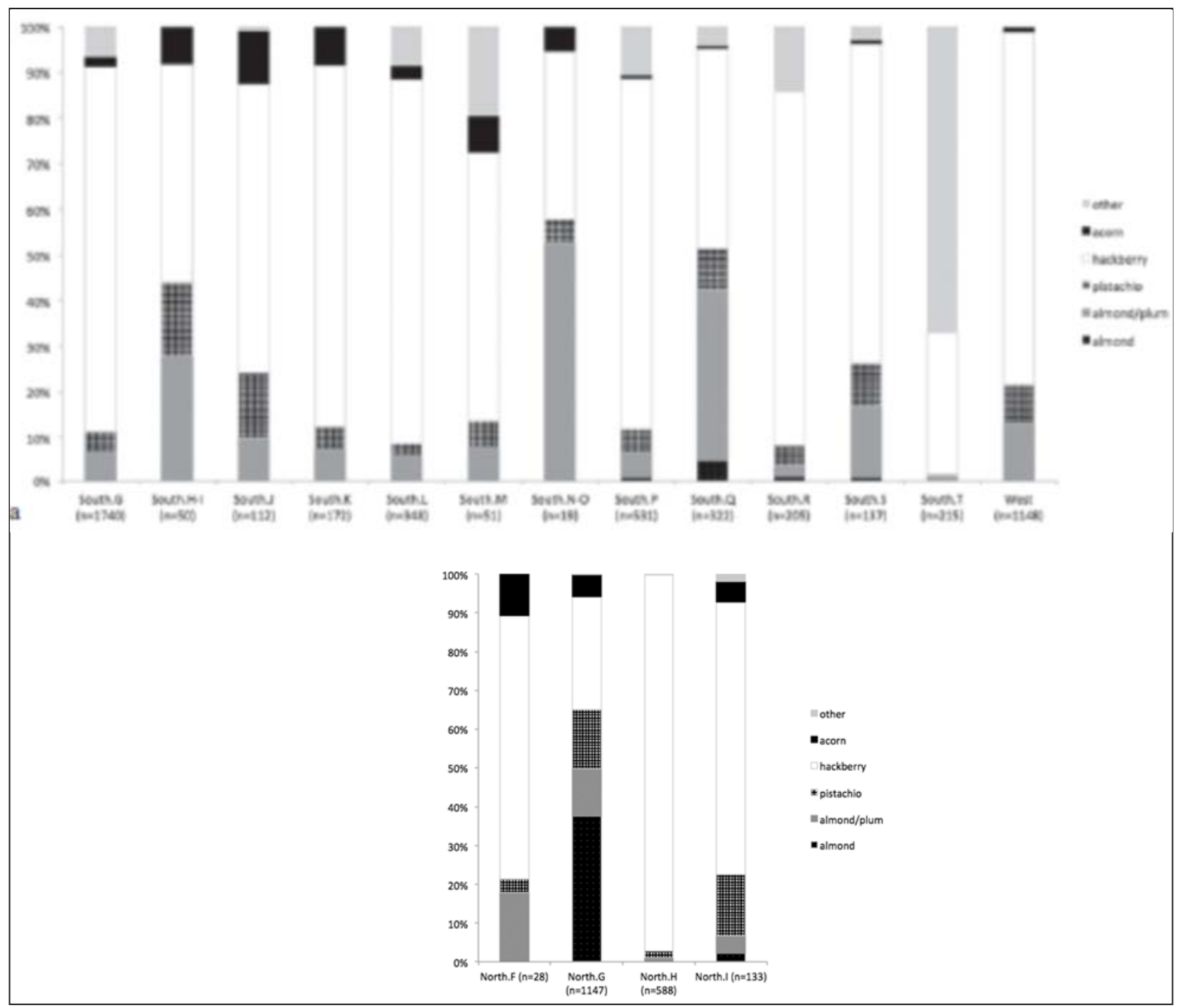

Fig. 13. Bar charts summarising proportions of fruit/nut taxa through time from (a) the South Area of the East Mound and the West Mound, and (b) the North Area of the East Mound. 

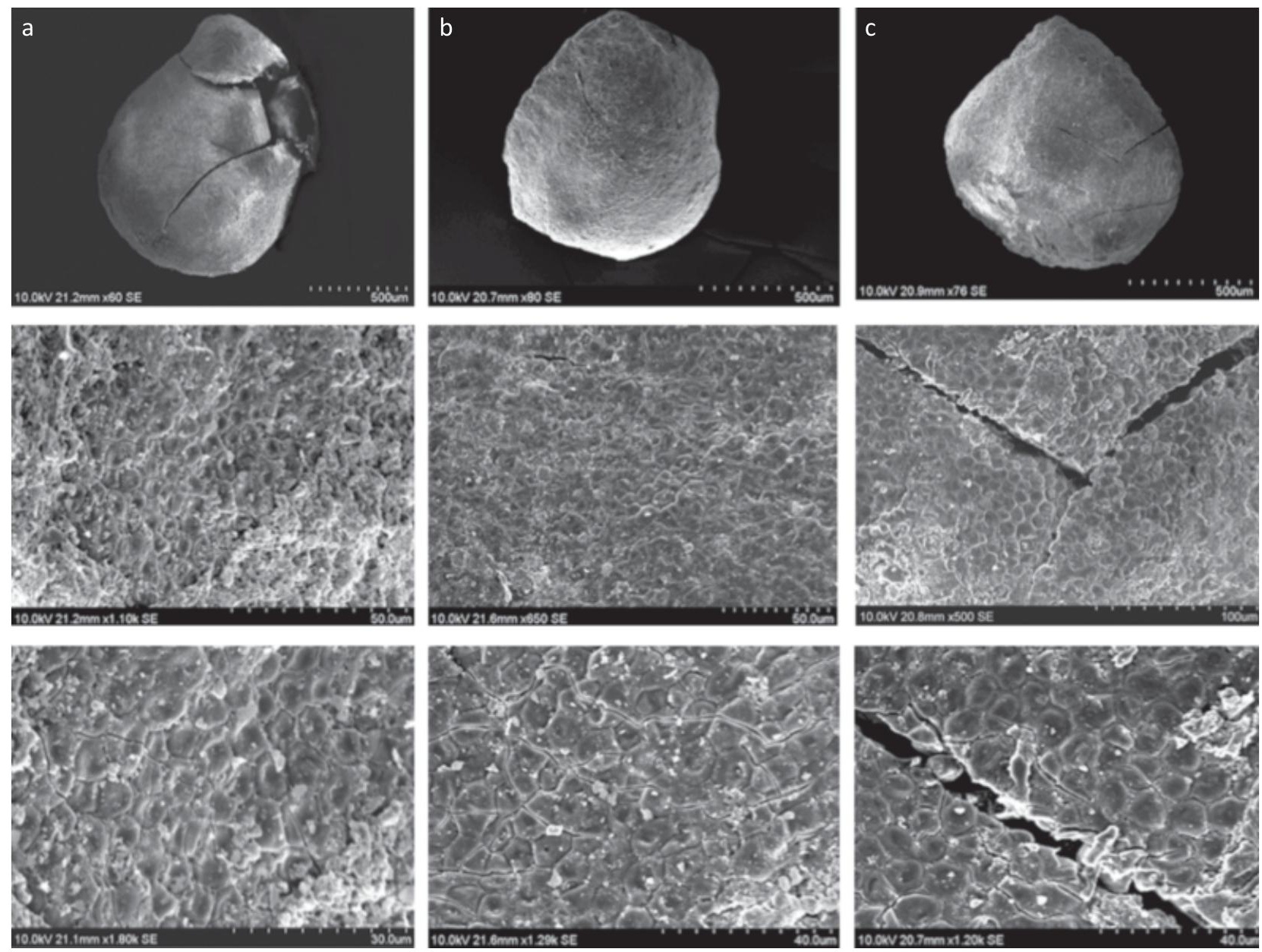

Fig. 14. Scanning electron microscope photographs of fig seeds: (a) and (b) from Çatalhöyük and (c) from Neolithic Halai, Greece (Diffey, Bogaard in preparation). 